\title{
Maternal obesity, duration of labor and the role of leptin
}

\author{
Sara Carlhäll
}

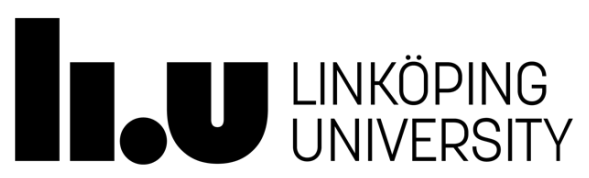

Department of Obstetrics and Gynecology

Department of Clinical and Experimental Medicine Linköping University, Linköping, Sweden Linköping 2018 
Maternal obesity, duration of labor and the role of leptin

(c) Sara Carlhäll, 2018

Cover:

Statue "Trudy” by Sissi Stahli. Photograph by Virtuelli Design.

Printed by LiU-Tryck, Linköping, Sweden, 2018

ISBN 978-91-7685-280-4

ISSN 0345-0082 
To my family 



\section{ABSTRACT}

Background: The prevalence of obesity substantially increases in pregnant women. Maternal obesity is associated with adverse maternal and neonatal outcomes. The increased risk for cesarean section present in obese women has been related to potential impaired uterine contractility. The mechanism that underlies this theory is not clear. In vitro studies have shown that leptin, produced by adipose tissue and the placenta, exerts an inhibitory effect on myometrial contractility. The aim of this thesis was to evaluate the labor process in relation to maternal body mass index (BMI) and the clinical role of leptin in this process.

Material and Methods: Studies I-IV are cohort studies. The first two studies analyze the association between labor duration and maternal BMI based on data from the Perinatal Revision South register and the Swedish Pregnancy Register. Study I included 63,829 nulliparous women with a spontaneous onset of labor between 1995 and 2009. Study II included 15,259 nulliparous women with induced labor between 2014 and 2017. In study III, the maternal leptin levels during and after pregnancy were analyzed in 343 obese women with respect to their obesity class (I-III) and degree of gestational weight gain (GWG). In study IV, the association between the maternal leptin levels measured in active labor and duration of the active phase of labor was analyzed in 914 women.

Results: The duration of spontaneous labor significantly increased with an increasing maternal BMI; however, the duration of the pushing phase was inversely related to BMI. Time in induced labor increased with maternal BMI; however, the differences between the BMI categories were more pronounced in the latent phase than the active phase. Leptin levels were higher in women with obesity class III than women with class I during and after pregnancy. The degree of GWG in obese women was not associated with maternal leptin. No significant association between maternal leptin and the duration of the active phase of labor was identified in the adjusted analyses.

Conclusions: Nulliparous obese women have a higher risk for a prolonged duration of spontaneous and induced labor. This is important to consider prior to diagnosing labor arrest that results in a cesarean delivery. As maternal leptin levels are increased with the degree of obesity during pregnancy, future research on the association of high maternal leptin levels and the duration of labor is warranted. 



\section{LIST OF SCIENTIFIC PAPERS}

I Maternal body mass index and duration of labor

Sara Carlhäll, Karin Källén and Marie Blomberg

Eur J Obstet Gynecol Reprod Biol. 2013;171:49-53

II The effect of maternal body mass index on duration of induced labor

Sara Carlhäll, Karin Källén and Marie Blomberg

Manuscript submitted

III Maternal obesity (class I-III), gestational weight gain and maternal leptin levels during and after pregnancy: a prospective cohort study

Sara Carlhäll, Marie Bladh, Jan Brynhildsen, Ing-Marie Claesson, Ann Josefsson, Gunilla Sydsjö, Annika Thorsell and Marie Blomberg BMC Obesity 2016 20;3:28

IV Maternal plasma leptin levels in relation to duration of the active phase of labor

Sara Carlhäll, Karin Källén, Annika Thorsell and Marie Blomberg Manuscript resubmitted after review 



\section{ABBREVIATIONS}

ACTH adrenocorticotropic hormone

ANC antenatal clinic

ANCOVA analyses of covariance

ANOVA analyses of variance

BMI body mass index

CAPs contraction associated proteins

COX cyklooxygenace

$\mathrm{CRH}$ corticotropin-releasing hormone

CS cesarean section

ELISA Enzyme-Linked ImmunoSorbent Assay

EMR electronical medical records

GDM gestational diabetes mellitus

GWG gestational weight gain

IOL induction of labor

IOM Institute of Medicine

LGA large for gestational age

PE pre-eclampsia

PRS Perinatal Revision South

SD standard deviation

SFOG Swedish Society of Obstetrics and Gynecology

SGA small for gestational age

WHO World Health Organization 



\section{CONTENTS}

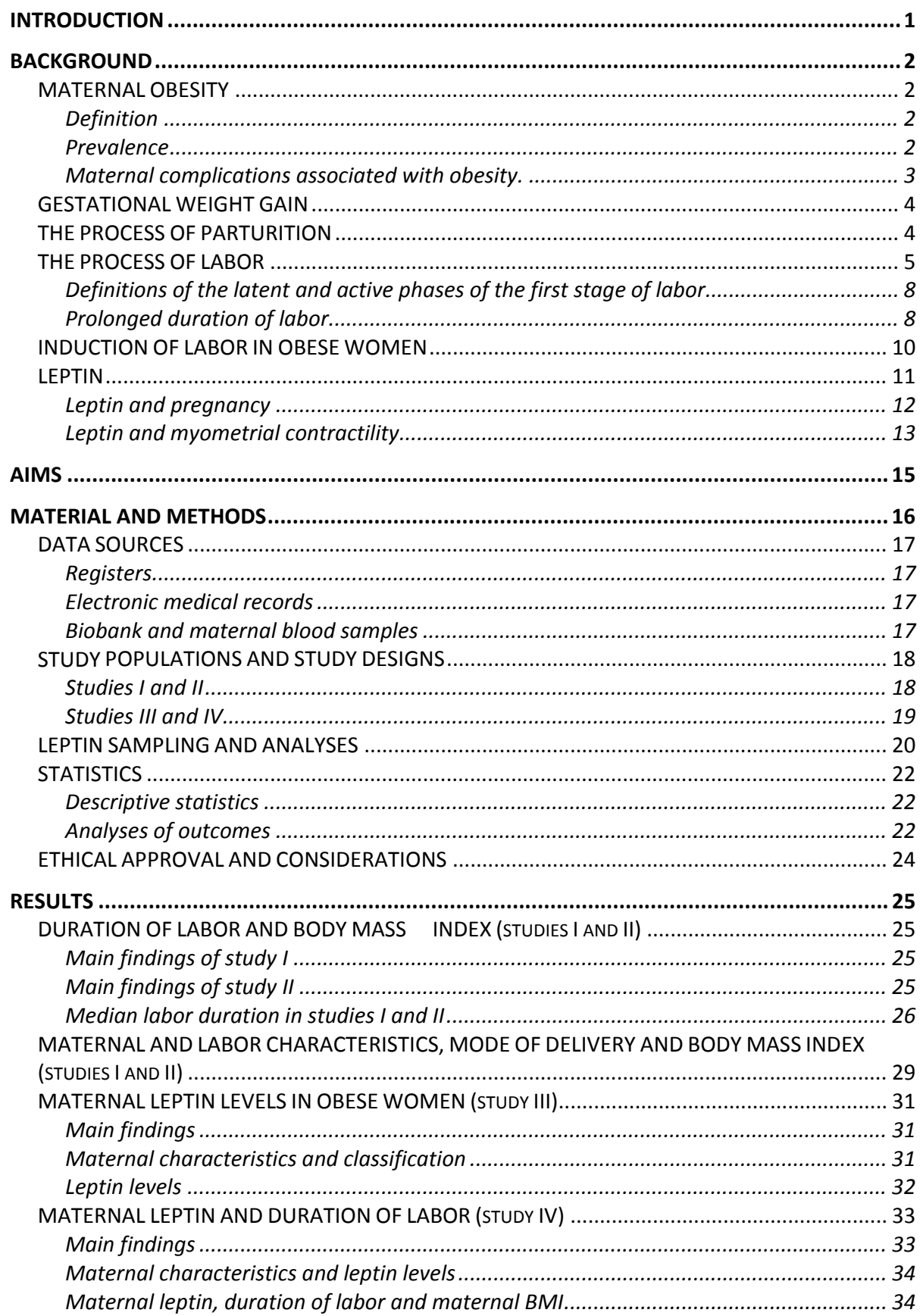




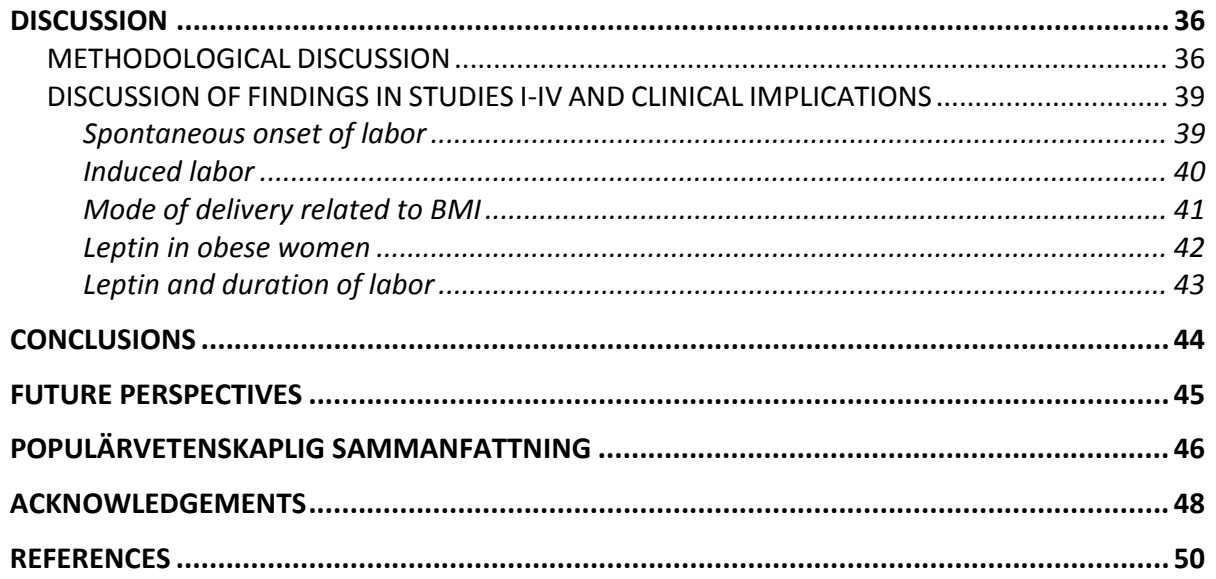




\section{INTRODUCTION}

Obesity in pregnant women has substantially increased over the previous several decades and has reached pandemic proportions. This trend is alarming because maternal obesity is accompanied by numerous adverse outcomes for both the mother and the child. Many of these maternal complications, including the well-documented increased risk for cesarean section (CS) have been related to a potential impaired uterine contractility in obese women. There are indications of a dysfunctional progression of labor in obese women. However, most previous studies on labor progression in relation to maternal body mass index (BMI) have included mixed parities and used different definitions of obesity. The reason for this ineffective uterine contractility has not been clarified. It has been demonstrated in vitro that myometrial fibers from obese women contract with less force end frequency than normal weight women. Other in vitro studies have shown that leptin, an adipokine produced by the adiposity tissue and the placenta, has an inhibitory effect on myometrial contractility.

The general aim of this thesis was to evaluate the labor process in relation to maternal BMI and the clinical role of leptin in this process. 


\section{BACKGROUND}

\section{MATERNAL OBESITY}

\section{Definition}

Obesity is defined as abnormal or excessive fat accumulation that may impair health. BMI is commonly used to classify overweight and obesity in adults (Table 1) (1). It is defined as an individual's weight in kilograms divided by the square of their height in meters $\left(\mathrm{kg} / \mathrm{m}^{2}\right)$. BMI correlates well with the proportion of body fat and is easy to measure; therefore, it is employed in clinical studies as a marker of health problems related to an increased amount of body fat.

Maternal obesity in pregnancy is typically defined as a BMI $\geq 30 \mathrm{~kg} / \mathrm{m}^{2}$ at the first antenatal consultation in early pregnancy (2).

Table 1. WHO classification of BMI

\begin{tabular}{|l|l|}
\hline BMI $\left.\mathbf{( k g} / \mathbf{m}^{2}\right)$ & Classification \\
\hline$<18.5$ & Underweight \\
\hline $18.5-24.9$ & Normal weight \\
\hline $25-29.9$ & Overweight \\
\hline $30-34.9$ & Obesity class I \\
\hline $35-39.9$ & Obesity class II \\
\hline$\geq 40$ & Obesity class III (morbid obesity) \\
\hline
\end{tabular}

\section{Prevalence}

Obesity has become a worldwide epidemic, and the prevalence of obesity in pregnant women or women of reproductive age has substantially increased in recent decades. The worldwide prevalence of obesity in women has doubled since 1975, and the global increase has not slowed down (3). In the USA, 34\% of women of reproductive age are obese, (4) and one of the highest rates in Europe is found in the United Kingdom, in which 26\% of women are obese (5). In Sweden, $40 \%$ of pregnant women are overweight or obese and the prevalence of obesity increased from 7\% in 1992 to $14 \%$ in 2016 (6) (Figure 1). 


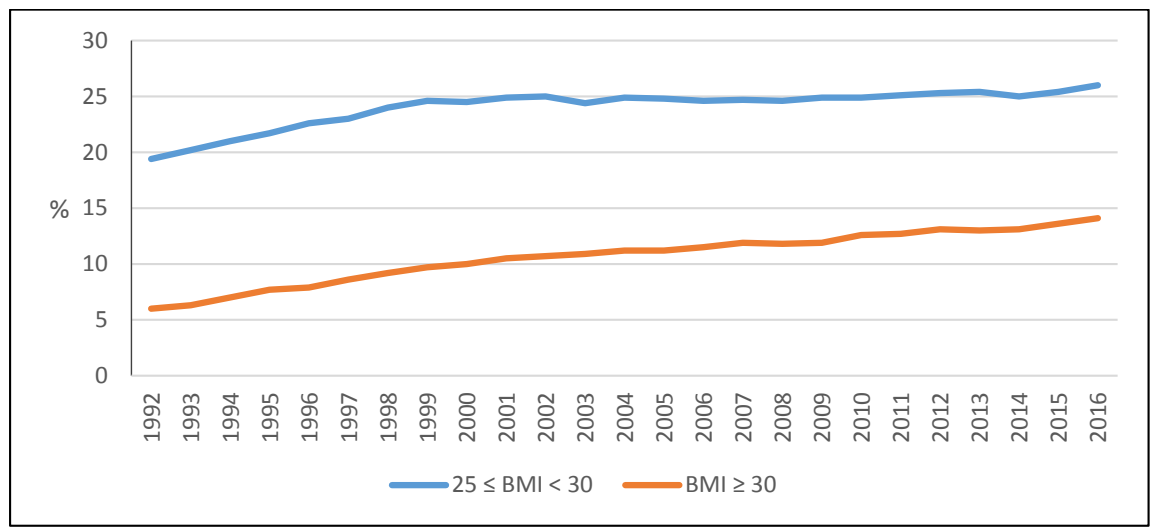

Figure 1. Proportion of pregnant women with overweight (BMI 25.0-29.9) and obesity (BMI $\geq 30.0)$ at registration for antenatal care in Sweden, 1992-2016

Source: The Swedish Medical Birth Register, National Board of Health and Welfare

\section{Maternal complications associated with obesity.}

Obese women have a higher risk of developing hypertension before and during pregnancy (gestational hypertension). Both conditions are associated with serious complications such as pre-eclampsia (PE), placental abruption, gestational diabetes mellitus (GDM), premature delivery and small for gestational age (SGA) (7). The risk of developing gestational hypertension is six times higher in obese pregnant women than in normal weight women (7). Maternal obesity is also associated with PE a potential life-threatening hypertensive disorder of pregnancy. Obese women have a three to eightfold higher risk of developing PE than normal weight women (7-9). Women who enter pregnancy obese are up to six times more likely to develop GDM than normal weight women (7). GDM implies a substantial risk to develop subsequent diabetes later in life, in addition to associated pregnancy complications such as PE, premature delivery, large for gestational age (LGA) and shoulder dystocia $(7,9,10)$. The risk for both PE and GDM is proportional to increasing maternal BMI $(8,10)$.

Obese women are more likely to experience complications during labor. Post-dated pregnancies, induction of labor (IOL) and abnormal labor progression are more common in obese women. The rates of both elective and emergency CS successively increase with maternal BMI (11-13). Postoperative complications, including postpartum hemorrhage, anesthesiology complications, infections and thromboembolic complications, are also more common in obese women $(9,14)$. 


\section{GESTATIONAL WEIGHT GAIN}

The total amount of weight gain during pregnancy varies among women and is a combination of fetal and uterus weight, amniotic fluid, the placenta, an increased maternal blood volume and maternal fat. A pronounced gestational weight gain (GWG) influences pregnancy outcome, however to a lesser extent than maternal obesity $(9,15)$.

In general, obese women gain less weight during pregnancy than normal weight women (16). The risk for a majority of the obesity related adverse outcomes during pregnancy may be amplified by excessive GWG $(17,18)$. Further, excessive GWG is associated with postpartum weight retention, which is an important indicator of obesity in midlife (19). Maternal weight retention between the first and second pregnancies is also associated with adverse pregnancy outcomes in the following pregnancy, even in normal weight women (20). Inadequate GWG is associated with small for gestational age and preterm birth (21).

In 2009, the American Institute of Medicine (IOM) published new guidelines on recommended weight gain during pregnancy according to prepregnancy BMI class (22) (Table 2). There are no specific recommendations within the different obesity classes. However, more recent studies indicate that women in higher obesity classes would benefit from lower GWG than recommended by the IOM. A GWG below the recommendations in morbidly obese women decreases the risk for LGA, gestational hypertension, PE and CS; however the risk increases for preterm birth and SGA $(18,23,24)$.

Table 2. The IOM recommendations for total weight gain during pregnancy

\begin{tabular}{|l|l|}
\hline Pre-pregnancy BMI $\mathbf{( k g / \mathbf { m } ^ { 2 }}$ ) & Recommended GWG (kg) \\
\hline$<18.5$ (underweight) & $12.5-18$ \\
\hline $18.5-24.9$ (normal weight) & $11.5-16$ \\
\hline $25-29.9$ (overweight) & $7-11.5$ \\
\hline$\geq 30$ (obese) & $5-9$ \\
\hline
\end{tabular}

\section{THE PROCESS OF PARTURITION}

The multifactorial process that regulates parturition and labor has been has been described in four phases. The phases correspond to the physiological changes in the myometrium and cervix during pregnancy as a result of hormonal and mechanical changes (14, 25-27) (Figure 2). 


Conception $\begin{aligned} & \text { Preparation } \\
& \text { changes }\end{aligned}$
\begin{tabular}{|l|l|l|l|l|}
\hline Phase & 1. Quiescence & 2. Activation & 3. Stimulation & 4. Involution \\
\hline Function & $\begin{array}{l}\text { Prelude to } \\
\text { labor }\end{array}$ & $\begin{array}{l}\text { Preparation for } \\
\text { labor }\end{array}$ & Process of labor & $\begin{array}{l}\text { Recovery of } \\
\text { labor }\end{array}$ \\
\hline $\begin{array}{l}\text { Clinical } \\
\text { changes }\end{array}$ & $\begin{array}{l}\text { Acontractile } \\
\text { phase. } \\
\text { Hormonal inhibi- } \\
\text { tors of myometri- } \\
\text { al contraction. } \\
\text { Cervix softens } \\
\text { close to phase 2. }\end{array}$ & $\begin{array}{l}\text { Cervical ripening } \\
\text { (changes in connective } \\
\text { tissue). Increased } \\
\text { myometrial irritability } \\
\text { and responsiveness to } \\
\text { contractile stimuli. } \\
\text { 个expression of CAPs. } \\
\text { Weakening of fetal } \\
\text { membranes. }\end{array}$ & $\begin{array}{l}\text { Uterine contrac- } \\
\text { tions. } \\
\text { Cervical thinning } \\
\text { (effacement) and } \\
\text { dilatation. } \\
\text { Fetal and placental } \\
\text { delivery. } \\
\text { Divided in 3 stages. }\end{array}$ & $\begin{array}{l}\text { Uterine involu- } \\
\text { tion. } \\
\text { Breast-feeding. } \\
\text { Cervical healing. }\end{array}$ \\
\hline $\begin{array}{l}\text { Essential } \\
\text { hor- } \\
\text { mones }\end{array}$ & $\begin{array}{l}\text { Progesterone, } \\
\text { relaxin, prostacy- } \\
\text { clin. }\end{array}$ & $\begin{array}{l}\text { Estriol, } \\
\text { prostaglandines, } \\
\text { placental CRH, fetal } \\
\text { ACTH, fetal cortisol, } \\
\text { cox 2. }\end{array}$ & $\begin{array}{l}\text { Prostaglandins, } \\
\text { oxytocin, relaxin. }\end{array}$ & $\begin{array}{l}\text { Oxytocin. } \\
\text { Inflammatory } \\
\text { pathways } \\
\text { initiated. }\end{array}$ \\
\hline Duration & $\begin{array}{l}\text { Most time of } \\
\text { pregnancy. }\end{array}$ & $\begin{array}{l}\text { Over weeks in the late } \\
\text { 3rd trimester. }\end{array}$ & $\begin{array}{l}\text { From start of labor } \\
\text { to delivery. }\end{array}$ & $\begin{array}{l}\text { Until restored } \\
\text { fertility. }\end{array}$ \\
\hline
\end{tabular}

Figure 2. The different phases of parturition.

\section{THE PROCESS OF LABOR}

The onset of labor in humans is a complex multifactorial process that is not completely understood. The process involves mechanical and hormonal interactions between the mother, the fetus and the placenta. These interactions include fetal and maternal hypothalamic-pituitary-adrenal axis activation, myometrial stretch and inflammation. The combination of the stimulatory factors triggers the onset of labor and transforms the myometrium from a quiescent to a contractile state (25). As in other smooth muscle cells, myometrial contractions are mediated through adenosine triphosphatase-dependent binding of myosin to actin, which is triggered by increased intracellular calcium ions $\left(\mathrm{Ca}^{2+}\right)$. Agents that stimulate myometrial contractions, such as prostaglandins and oxytocin, act on myometrial cells to increase the intracellular $\mathrm{Ca}^{2+}$ release from the sarcoplasmic reticulum or allow an influx of extracellular $\mathrm{Ca}^{2+}$ through ligand- or voltage-regulated calcium channels $(14,28)$. The process of labor is divided into three stages of labor (Figure 3). 

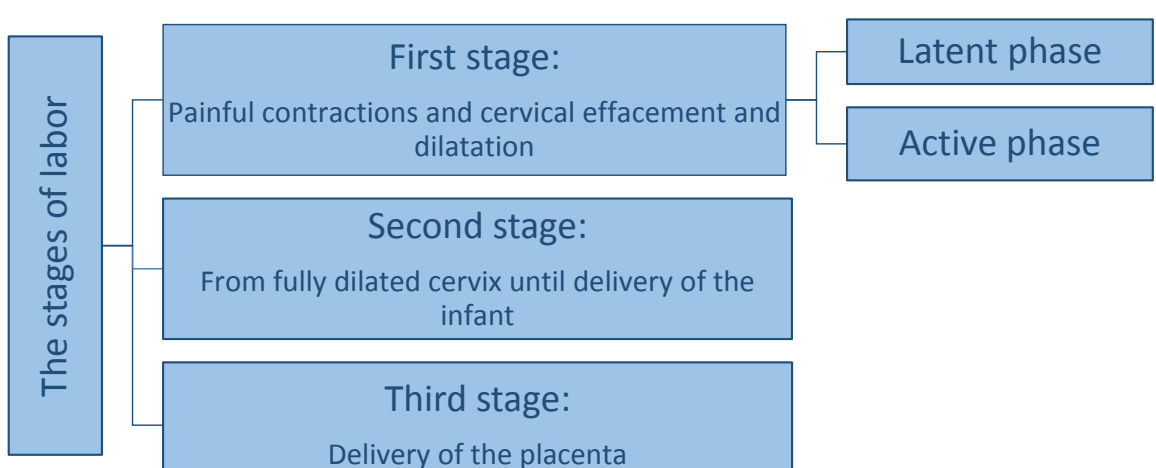

\section{Second stage:}

\section{From fully dilated cervix until delivery of the} infant

\section{Third stage:}

Delivery of the placenta

Figure 3. The stages and phases of the process of labor.

Research conducted by Friedman in the 1950s on the labor progress in 500 nulliparous women was presented as a sigmoid curve that illustrated the first stage of labor and has defined the normal course of labor world-wide for decades (29) (Figure 4). As the evaluation of the labor progression was based a small homogenous cohort that gave birth more than half a decade ago, it has been questioned whether this curve can be applied to current obstetrical care. Currently, the laboring women are older, have higher BMI and deliver by CS to a larger extent. Furthermore, the different obstetrical interventions that are more commonly used (inductions, epidural anesthesia and oxytocin use) may affect the labor process. Recent studies suggest that labor progression in contemporary labor cohorts differs from Friedman's results (30-33). A longer duration of the active phase and a later transition from the latent to the active phase than previously described have been reported (30-32). In a study on 62,415 nulli- and multiparous women with a term singleton pregnancy, spontaneous onset of labor and vaginal delivery, Zhang et al determined that labor progressed more slowly between 4-6 cm than previously described by Friedman and that the acceleration phase started at a cervical dilatation of $6 \mathrm{~cm}$ (30) (Figure 5). Oladapo et al studied labor patterns of 5,606 nulli-and multiparous women in a sub-Saharan African population and found, similar to Zhang et al, greater individual variability in labor progression than generally appreciated and that the acceleration phase may not start until $5 \mathrm{~cm}$ cervical dilatation (33). 


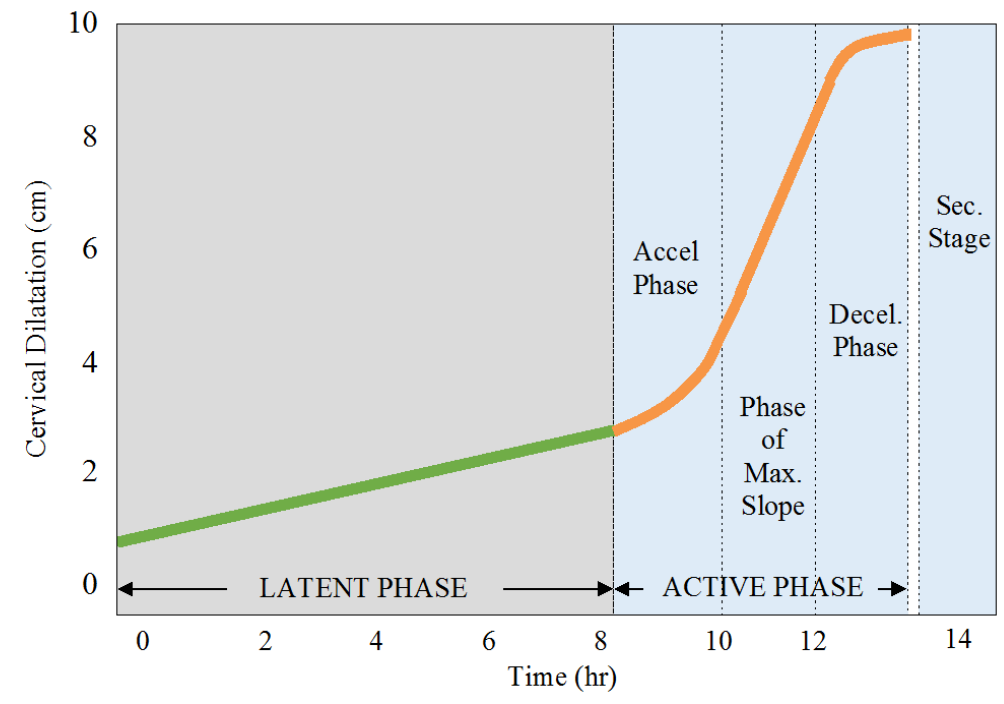

Figure 4: Friedman's labor curve. Friedman. Primigravid Labor, A graphicostatistical analysis. Obstet and Gynecol 1955.

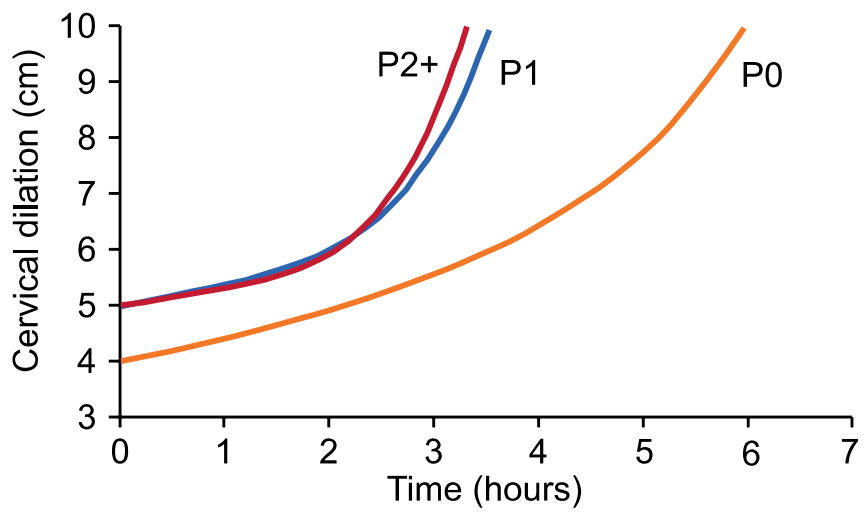

Figure 5: Zhang's labor curves. Average labor curves by parity in singleton, term pregnancies with spontaneous onset of labor, vaginal delivery and normal neonatal outcomes. P0: nulliparous; P1: women of parity one; P2+: women of parity two or higher. Zhang, Obstet and Gynecol 2010. 


\section{Definitions of the latent and active phases of the first stage of labor}

The latent phase has been described to start with (irregular) painful uterine contractions, changes in cervical effacement and initial dilatation (34). It ends when the active phase starts. However, partly as a result of the lack of an international consensus regarding what time the active phase commences, the latent phase is commonly ill defined (35). According to the Swedish Society of Obstetrics and Gynecology's (SFOG) definition of the International Classification of Diseases, 10th revision (ICD-10), a prolonged latent phase is defined as more than 18 hours. A long duration of the latent phase of labor has been associated with an increased risk of CS, oxytocin augmentation and admission to the neonatal intensive care unit (36).

The active phase of the first stage of labor (referred to as the active phase) is commonly defined to start at a cervical dilatation of 3-4 cm together with painful uterine contractions, and it ends when the cervix is fully dilated. The threshold of 3-4 cm of cervical dilatation for defining the start of the active phase is based on the Friedman curve and is used in the definitions by the NICE (National Institute for Health and Care Excellence) guidelines (34) and have been used by the World Health Organization (WHO) (37) until recently. In February 2018 the WHO published new recommendations on intrapartum care presenting a cervical dilatation of $5 \mathrm{~cm}$ as a threshold for entering the active phase of labor $(38,39)$. The Swedish guidelines by the National Board of Health and Welfare from 2001 recommend that two of the following three criteria should be fulfilled for start of the active phase: cervical dilatation of 3-4 cm, three or more regular contractions $/ 10$ minutes and rupture of the amniotic membranes (40). A revised recommendation was proposed by the Swedish Association of Midwifes and SFOG in 2015, which indicated that two of three criteria should be fulfilled for the start of the active phase: dilatation of the cervix of $4 \mathrm{~cm}$ or complete effacement of the cervix and dilatation $>1 \mathrm{~cm}, 2-3$ regular spontaneous painful contractions or spontaneous rupture of membranes and in addition to a progression of labor within the following two hours (41). However, the extent to which this revised recommendation is used remains unclear. The guidelines from the American Collage of Obstetricians and Gynecologists in 2014 recommends that a cervical dilation of $6 \mathrm{~cm}$ should be considered the threshold for the active phase of most women in labor (42).

\section{Prolonged duration of labor}

Different terms for a prolonged duration of the active phase include labor dystocia, failure to progress and obstructed labor. Traditionally, it has been defined as no dilatation in two hours or a dilatation rate less than 1.2 
$\mathrm{cm} /$ hour. In a large American cohort, nulliparous women with prolonged active labor had higher odds for cesarean delivery and chorioamnionitis but not an adverse neonatal outcome (43). In another large American cohort of women who all reached $10 \mathrm{~cm}$ dilatation, Harper et al demonstrated that a prolonged labor increased the risk of maternal fever, a prolonged second stage, shoulder dystocia, and adverse neonatal outcomes (44).

There appears to be a normal physiological variation in the duration of labor, particularly in early labor, which may not be linear from 3-4 cm of cervical dilatation according to recent studies on contemporary cohorts of women in labor $(30,31,33)$. The effectiveness of uterine contractions and the duration of labor may be influenced by numerous factors such as parity, fetal position and size and pelvic size and shape, maternal psychological state and maternal obesity $(25,45)$.

\section{ONSET AND PROGRESSION OF LABOR IN OBESE WOMEN}

Maternal obesity is associated with a longer gestation and an increased risk of post term pregnancy. It has been demonstrated that as maternal BMI increases, the chance of a spontaneous start of labor decreases $(46,47)$. The risk for post-term pregnancies, defined as a gestational length of more than 42 completed weeks from the last menstrual period, also increases with maternal BMI (48).

During labor, the process of cervical dilation is slower in obese women than normal weight women $(25,49,50)$ and the duration of active labor increases with maternal BMI (45). It appears as if the prolonged duration of labor in obese women is restricted to the active phase of labor, particularly before $6-7 \mathrm{~cm}$ of cervical dilatation (45, 49-51). This is supported by studies that indicate the duration of the second stage of labor in nulliparous women is similar irrespective of maternal BMI $(45,52)$ and that the pushing ability is not related to maternal BMI (53).

The dose-dependent relationship between an increasing maternal BMI and a higher risk for cesarean delivery remains even after adjusting for obesityassociated co-morbidities $(11,54)$. The risk appears to be confined to the active phase of labor (54) and is mainly a result of a failure to progress /dysfunctional labor (55-57). When labor dystocia or failure to progress is diagnosed, augmentation with oxytocin is recommended. Oxytocin is administered according to a standard regimen regardless of BMI. However, 
there are studies indicating that obese women have higher oxytocin requirements during the induction of labor $(58,59)$.

The exact mechanism of dysfunctional labor in obese women is not completely understood and is presumably multifactorial. Obesity is a chronic inflammatory state characterized by hyperinsulinemia and dyslipidemia. Adipose tissue has neuroendocrine functions that produce adipokines and cytokines, which may influence the onset and progression of labor. However, given the multiple labor abnormalities that are more common in obese women, including an increased risk for post-term pregnancies, slow progress and prolonged duration of labor, oxytocin for augmentation, postpartum hemorrhages and CS, the leading theory is that obesity may be associated with impaired myometrial contractility $(25,56,57)$. This theory is supported by Zhang et al who demonstrated in an in vitro study that myometrium obtained from obese women undergoing an elective CS at term contracted spontaneously with less force and frequency than myometrial fibers from normal weight women (55). The difference in contractility ability was explained by demonstrated alterations in intracellular $\mathrm{Ca}^{2+}$ as myometrial fibers from obese women had less $\mathrm{Ca}^{2+}$ flux. (55). However, in a similar in vitro study, no correlation was identified between maternal BMI and spontaneous myometrial activity; this study included fewer myometrial biopsies from obese women compared the study by Zhang et al (60). Muir et al identified asynchronous myometrial contractility in obese laboring rats compared to synchronous contractions in lean animals. They also identified adverse alterations in uterine contractile protein expression and progesterone production in obese animals compared to lean animals (61).

\section{INDUCTION OF LABOR IN OBESE WOMEN}

Induction of labor (IOL) has become a common intervention in contemporary obstetrical practice. In Sweden, the proportion of induced singleton deliveries at full-term pregnancy ( $\geq 37$ full gestational weeks) increased from $7.4 \%$ in 1991 to $17.8 \%$ in 2016 (6). Nulliparous women with IOL are three to four times more likely to have a cesarean delivery compared to nulliparous women with a spontaneous onset of labor $(62,63)$. Among women with induced labor the risk of a cesarean delivery increases further with maternal obesity (64-67). Unfortunately, obese women are more likely to undergo IOL compared to normal weight women (64-66). This is explained, in part, by the positive association between maternal obesity and post-term pregnancy (46-48). The increased rates of obesity associated comorbidities such as PE, GDM and hypertension, also contributes to the greater need of IOL $(59,63)$. 
Considering the increasing prevalence of obesity and the associated risk for a cesarean delivery, obese nulliparous women with IOL represent a challenging risk group in contemporary obstetrical care. It has been demonstrated that the duration of the total time in induced labor increases with a higher maternal weight at the time of delivery $(45,59,67,68)$ and failure to progress is a more common indication for cesarean delivery in obese women with IOL than normal weight women $(69,70)$. Limited studies have assessed the effect of maternal early pregnancy BMI on the duration of induced labor, with contradictory results $(58,64,71)$.

Studies that have compared labor lengths of spontaneous and induced labor, without relation to maternal BMI, also show contradictory results (72, 73). If induced labor is longer perhaps some CSs in women with IOL as a result of no progress are performed prematurely? This question is raised by Harper et al who determined that nulliparous women with IOL spent a longer time in labor than women with a spontaneous onset of labor (73).

\section{LEPTIN}

In the search for biological linkages between maternal obesity and adverse outcomes during pregnancy, the adipokine leptin is of substantial interest. Adipose tissue is now recognized not only as the main site for energy storage but also as an endocrine organ that secrets bioactive substances. These substances are referred to as adipokines, cell-signaling proteins, that are involved in energy homeostasis and have pro- or anti-inflammatory activities (74). Leptin is one adipokine. It is mainly produced by white adipose tissue, is principally associated with the regulation of energy metabolism and acts as a central satiety-signaling hormone. Obesity is associated with increasing serum leptin levels, proportional to the BMI and percentage of body fat in humans $(75,76)$. This paradoxical effect of increased levels of leptin in obese humans may be explained, in part, by a loss of signaling capacity to central satiety centers that may occur as a result of leptin resistance, which results in high leptin levels without the expected anorectic response (74).

Leptin is thought to have pro-inflammatory effects and promotes the production of pro-inflammatory cytokines (77). Leptin's actions are mediated by acting on leptin receptors in different target tissues. There are five known isoforms of leptin receptors. Four isoforms are membrane bound, and the full-length receptor $\mathrm{Ob}-\mathrm{Rb}$ is primarily responsible for leptin- 
signaling. $\mathrm{Ob}-\mathrm{Rb}$ is expressed in the endometrium, myometrium, placenta and umbilical cord (77).

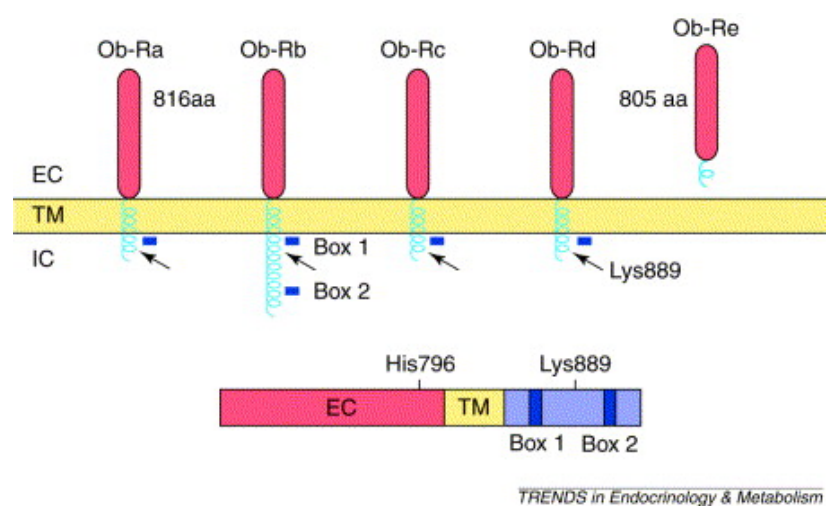

Figure 6. The isoforms of the leptin receptor. Caprio. Leptin in reproduction. Trends Endocrinol Metab. 2001

Other factors, in addition to the amount of adipose tissue that influence the leptin levels include gender, age, puberty, fasting, feeding and prolonged strenuous exercise (78). Leptin has also shown a diurnal pattern, with peak values during the night and lower values during the afternoon. However, it has been indicated that this pattern relates to food intake rather than the circadian clock (78). It has also been shown that plasma leptin levels measured in the fasting state are stable and reproducible in lean and obese men and women (79).

\section{Leptin and pregnancy}

During pregnancy, the placenta also produces leptin. Irrespective of maternal BMI, leptin levels substantially increase during a normal pregnancy, peak in the late second or early third trimester and return to pre-pregnancy levels after delivery, which indicates an important role for normal fetal development and growth (80-82). In normal pregnancies, there appears to be a central leptin resistance, which is beneficial for adequate energy supply to the fetus (80). An important placental function is to prevent embryo rejection by the maternal immune system. Leptin appears to have an important role as an immune-modulator in the placenta (77).

Leptin levels are higher in obese pregnant women than normal weight women during the whole pregnancy (82-84). It has also been shown that although leptin concentrations in overweight and obese women are higher, they increase at a lower rate across gestation compared to normal weight women $(85,86)$. 
Although leptin appears to be of importance during a normal pregnancy, increased levels of leptin have been associated with adverse maternal pregnancy outcomes. The pro-inflammatory actions of leptin may be of importance in the pathogenesis of obesity associated pregnancy disorders, such as PE and GDM characterized by hyperleptinemia, leading to increased levels of pro-inflammatory mediators present in these diseases (77, 87-89). It may also contribute to the placental inflammation present in obese pregnant women which may result in placental damage and altered function (80).

\section{Leptin and myometrial contractility}

There are no published studies on the effect of leptin on human myometrial contractility in vivo. However, several authors have analyzed the effect of leptin on myometrial muscle cells in vitro and have suggested that leptin may play a role in the regulation of myometrial activity and obesity related parturition complications (90-94).

Moynihan el al. analyzed myometrial biopsies from pregnant non-laboring women who underwent elective CS at term. They determined that leptin had a cumulative inhibitory effect on both spontaneous and oxytocininduced contractions in all myometrial strips in vitro (92). In a similar study, this in vitro cumulative inhibitory effect of leptin on contractions in pregnant human myometrial biopsies was confirmed (94). Wendremaire et al proposed that elevated leptin levels may play a role in obesity related delivery disorders, by demonstrating that leptin prevented remodeling of myometrial extracellular matrix, which is necessary for effective uterine contractions during labor (91), and leptin inhibits myometrial apoptosis, which is of importance for uterine smooth muscle to change from a proliferative to contractile status (90). Barrichon et al showed in vitro that leptin induced human myometrial proliferation. This proliferative effect on the myometrial cells lead to the maintenance of uterine quiescence and thereby opposed the mechanisms that trigger labor and myometrial contractions (93). These findings have led to speculations regarding whether leptin could be used as a tocolytic agent $(93,95)$.

The mechanism by which leptin mediates this inhibitory effect on myometrial contractility is unknown. It has been speculated that if leptin has the same function in the uterine smooth muscle cells as in vascular smooth muscle and reduces intracellular calcium $\left[\mathrm{Ca}^{2+}\right]$ release, it may impair the contractility ability of the myometrium (96). This thought was supported by Zhang et al, who demonstrated that myometrium from obese women contracted with reduced frequency and amplitude in vitro. Simultaneous measurements of intracellular $\left[\mathrm{Ca}^{2+}\right]$ showed less $\left[\mathrm{Ca}^{2+}\right]$ flux in the myometrium of obese women than normal weight women (55). 
Based on clinical experience, and the results from the aforementioned clinical studies and in vitro studies, we hypothesized that duration of both spontaneous and induced labor would be longer in obese women than in normal weight women. As leptin has been associated with hypertensive disorders during pregnancy and GDM, that are more common in obese pregnant women, and had an in vitro relaxing effect on myomterial contractility we hypothesized that leptin would be higher with increasing maternal obesity class. Further we hypothesized that leptin would have a relaxing effect on myometrial contractility in vivo, resulting in a prolonged duration of labor, regardless of maternal BMI. 


\section{AIMS}

\section{General aim}

The general aim of this thesis was to evaluate the labor process in relation to maternal BMI and the clinical role of leptin in this process.

\section{Specific aims}

\section{Study I}

To evaluate whether duration of the active labor is associated with maternal pre-pregnancy BMI in nulliparous women with a spontaneous onset of labor and to evaluate the duration of the second stage of labor in relation to maternal BMI separately.

\section{Study II}

To evaluate whether the durations of the latent and active phases of labor are associated with early pregnancy maternal BMI in nulliparous women with induced labor.

\section{Study III}

To estimate whether maternal plasma leptin levels during and after pregnancy are associated with different degrees of maternal obesity and different levels of GWG.

\section{Study IV}

To analyze the relationship between the duration of the active phase of labor and maternal plasma leptin levels measured at the time of delivery. 


\section{MATERIAL AND METHODS}

A brief overview of the subjects and methods of the four studies is presented in table 3 below.

Table 3. Overview of the studies included in the thesis

\begin{tabular}{|c|c|c|c|c|}
\hline PAPER & I & II & III & IV \\
\hline Design & Cohort study & $\begin{array}{l}\text { Population based } \\
\text { cohort study }\end{array}$ & Cohort study & Cohort study \\
\hline Years & $1995-2009$ & $\begin{array}{l}\text { Jan } 2014 \text { - Aug } \\
2017\end{array}$ & $\begin{array}{l}\text { Nov } 2003-\text { Dec } \\
2005\end{array}$ & April 2014 - Dec 2015 \\
\hline $\begin{array}{l}\text { Data } \\
\text { sources }\end{array}$ & $\begin{array}{l}\text { Perinatal Revision } \\
\text { South register }\end{array}$ & $\begin{array}{l}\text { Swedish Pregnan- } \\
\text { cy Register }\end{array}$ & $\begin{array}{l}\text { Electronic med- } \\
\text { ical records and } \\
\text { biobank }\end{array}$ & $\begin{array}{l}\text { Electronic medical } \\
\text { records and biobank }\end{array}$ \\
\hline Subjects & $\begin{array}{l}63,829 \text { nulliparous } \\
\text { with spontaneous } \\
\text { onset of labor }\end{array}$ & $\begin{array}{l}15,259 \text { term nul- } \\
\text { liparous with in- } \\
\text { duced labor }\end{array}$ & $\begin{array}{l}343 \text { obese } \\
\text { pregnant wom- } \\
\text { en }\end{array}$ & $\begin{array}{l}914 \text { term nulli and } \\
\text { multiparous women }\end{array}$ \\
\hline Exposures & Maternal BMI & Maternal BMI & $\begin{array}{l}\text { Maternal obesi- } \\
\text { ty class and } \\
\text { degree of GWG }\end{array}$ & $\begin{array}{l}\text { Maternal plasma lep- } \\
\text { tin levels in active } \\
\text { labor }\end{array}$ \\
\hline $\begin{array}{l}\text { Outcome } \\
\text { measures }\end{array}$ & $\begin{array}{l}\text { Duration of labor } \\
\text { with a spontaneous } \\
\text { onset }\end{array}$ & $\begin{array}{l}\text { Duration of the } \\
\text { latent and active } \\
\text { induced labor }\end{array}$ & $\begin{array}{l}\text { Maternal leptin } \\
\text { levels during } \\
\text { pregnancy and } \\
\text { postpartum }\end{array}$ & $\begin{array}{l}\text { Duration of the active } \\
\text { phase of labor }\end{array}$ \\
\hline Covariates & $\begin{array}{l}\text { Maternal age, birth } \\
\text { weight, year of de- } \\
\text { livery }\end{array}$ & $\begin{array}{l}\text { Maternal age, } \\
\text { birth weight, } \\
\text { GWG (smoking } \\
\text { and vaginal deliv- } \\
\text { ery in active labor } \\
\text { analyses) }\end{array}$ & & $\begin{array}{l}\text { Parity, use of EDA or } \\
\text { oxytocin, birth weight, } \\
\text { induction. (Parity, } \\
\text { gestational age, EDA } \\
\text { and oxytocin in spon- } \\
\text { taneous labor anal- } \\
\text { yses) }\end{array}$ \\
\hline Statistics & $\begin{array}{l}\text { Descriptive statistics, } \\
\text { Kruskal-Wallis, } \\
\text { ANOVA, ANCOVA, } \\
\text { multiple logistic } \\
\text { regression analyses } \\
\text { and Kaplan-Meier } \\
\text { analysis }\end{array}$ & $\begin{array}{l}\text { Descriptive statis- } \\
\text { tics, one-way } \\
\text { ANOVA, ANCOVA } \\
\text { and cox regres- } \\
\text { sion analyses }\end{array}$ & $\begin{array}{l}\text { Descriptive } \\
\text { statistics and } \\
\text { two-way } \\
\text { ANOVA model } \\
\text { (Bonferroni } \\
\text { adjusted) }\end{array}$ & $\begin{array}{l}\text { Descriptive statistics, } \\
\text { univariate and } \\
\text { multiple linear } \\
\text { regression analyses } \\
\text { and Kaplan-Meier } \\
\text { analysis }\end{array}$ \\
\hline
\end{tabular}




\section{DATA SOURCES}

\section{Registers}

Data from two different registers were used in studies I and II. The perinatal Revision South (PRS) register, which was used in study I, is a regional perinatal database in southern Sweden, instituted in 1995 and based on approximately 17,600 annual births at nine obstetric units in the region. The database closed in 2015 (97).

The population-based cohort (study II) was based on data from the Swedish Pregnancy Register (www.graviditetsregistret.se) (98). The register was established in 2013 by merging the Maternal Health Care register and the National Quality Register for Prenatal Diagnosis and collecting information from deliveries in electronic medical records (EMRs). The register currently contains information on maternal characteristics, pregnancy complications, labor and birth data from $90 \%$ of all deliveries in Sweden. The majority of the variables included in the register are continuously transferred electronically from the medical antenatal, labor and delivery records. A few variables are manually registered by midwifes at the antenatal care (ANC) clinics. These data include information on country of birth, level of education and diagnosis of GDM (98).

\section{Electronic medical records}

For studies III and IV, pregnancy and delivery data were collected from the electronic medical record (EMR) system Obstetrix ${ }^{\circledR}$. Information on all pregnant women in the Region Östergötland who attend the maternal ANC clinics is recorded in Obstetrix ${ }^{\circledR}$ (Cerner). This EMR system contains detailed, prospectively registered information for each pregnancy from the first visit until the mother and infant are discharged from the delivery hospital. These data include maternal reproductive, demographic and health data, prenatal maternal medical diagnoses and pregnancy outcome for the mother and infant.

\section{Biobank and maternal blood samples}

For leptin analyses in study III, we used saved maternal blood samples from a previous intervention study on weight gain during pregnancy (99). The women were recruited from the ANC clinic in Linköping and two other nearby ANC clinics (Norrköping and Värnamo). For leptin analyses in study IV, we used maternal blood samples from women included in "GRABB", a local pregnancy biobank. The maternal blood samples in both studies III and IV were handled similarly and stored in a common biobank 
with register number 185 at the Department of Obstetrics and Gynecology, Östergötland County Council.

"GRABB" is a research project in which all women at the ANC clinic in Linköping are asked to participate with the aim to collect blood samples from pregnant women to build a biobank for future research. It was initiated in 2011, and the aim is to collect samples from 8000 individuals. Blood samples are collected at the same time as routine blood tests are performed, including twice during pregnancy, as well as at the time of delivery from 2014. To date, approximately $55 \%$ of all women who have been registered for antenatal care during this time period have agreed to participate in "GRABB".

\section{STUDY POPULATIONS AND STUDY DESIGNS}

\section{Studies I and II}

\section{Study populations}

Studies I and II are large cohort studies that include nulliparous women with a singleton pregnancy. Study I included 63,829 women with a spontaneous onset of labor from 1995 until 2009. Of these women, 57,500 women also had information on time in the second stage of labor. Study II is population based and included 15,259 women with IOL from January 2014 until August 2017. Women with non-available information on the start of active labor and the time of birth and missing maternal BMI were excluded from studies I and II. Additional exclusion criteria in study II included stillbirth and no information on maternal age. Women with a CS during the active phase of labor were included in both studies; however, women with a cesarean delivery in the second stage in study $\mathbf{I}$ or the latent phase in study II were not included.

\section{Exposure}

The exposure in studies I and II was pre-pregnancy or early pregnancy maternal BMI. BMI was calculated based on self-reported pre-pregnancy weight or measured weight and height in the first trimester in study I. In study II, BMI was calculated based on the maternal weight and height measurements provided at the first antenatal visit between gestational weeks 8 and 10 in a majority of the study patients. The study population was categorized in six classes of BMI according to the WHO definition (Table 1). 


\section{Outcomes}

Time in labor was the main outcome in studies I and II. The time estimates on labor that are available in the PRS register and in the Swedish Pregnancy Register include the start of the active phase of labor, start of pushing efforts and time of birth. In study I, the labor outcomes included the duration of active labor, defined as from the start of the active phase of labor until the time of birth, and the second stage of labor. As there was no information in the PRS register on the time when the cervix was fully dilated, we defined the second stage as from the start of the pushing efforts until the time of birth. In study II, the main outcomes included the duration of the latent and active labor. The active labor was defined as in study I. Information on the start of induction is not available in the Swedish Pregnancy Register; however, the time of arrival to the delivery ward for the IOL is available. In Sweden, most patients admitted for IOL start induction shortly after arrival to the delivery ward; therefore, we used the time of arrival as a proxy for the start of IOL. Thus, latent labor was defined from the time of the arrival to the delivery ward for IOL until the start of the active phase of labor. Another outcome in study II was the rate of emergency CS in the active labor and other modes of delivery. As the inclusion criteria in study II comprised information on the time of the start of the active phase of labor, all women who did not reach the active phase were not included. Therefore, women who had a CS in the latent phase were not included in the study population.

\section{Studies III and IV}

\section{Study populations}

In studies III and IV, we used cohorts from the south-eastern health care region of Sweden. In study III, we analyzed 343 obese pregnant women with a singleton pregnancy from three ANC clinics included in a previous intervention study on weight gain during pregnancy (99). The exclusion criteria in the original study were a pre-pregnant diagnosis of diabetes mellitus, thyroid dysfunction or psychiatric disease treated with neuroleptic drugs. In study IV, we included 914 nulli- and multiparous women who were included in the local biobank GRABB at the first antenatal visit at the ANC clinic in Linköping and who delivered at the Linköping University Hospital. Women with multiple pregnancies, diabetes mellitus, intrauterine fetal death, premature labor (gestational week $<37+0$ ), elective CS, a missing leptin value or incomplete information on the time estimates of the active phase of labor were excluded. Thus, all women who had undergone an emergency CS during the active phase of labor (before pushing efforts started) were excluded. In study IV, 766 women, out of the 914 women 
included in the study, had a spontaneous onset of labor and were also analyzed separately. Further in study IV, 660 women had information on GWG and were categorized in three classes of GWG according to the recommended weight gain based on their early pregnancy BMI and the IOM's guidelines (Table 2).

\section{Exposures}

The exposures in study III included the degree of early pregnancy maternal obesity and degree of GWG. The study population was categorized in three obesity classes according to the WHO definition on obesity classes IIII (Table 1 and Figure 14) and was divided into three groups of GWG based on the IOM guidelines advising optimal weight gain during pregnancy (Table 2 and Figure 14).

The exposure in study IV included the maternal plasma leptin value measured in active labor. Maternal plasma was collected shortly after the women had arrived to the delivery ward as soon as she was assessed to be in active labor.

\section{Outcomes}

The outcome in study III included maternal leptin levels during pregnancy and postpartum. Maternal plasma leptin levels were measured in gestational weeks 15 and 29 and 10 weeks postpartum. The women fasted prior to sampling of the maternal blood, which was performed in the morning in all patients. The blood samples were handled as in study IV and were stored in the same biobank. The outcome in study IV time included the duration of the active phase of labor. The duration of the active phase of labor was defined as from the start of active labor until the start of pushing efforts.

\section{LEPTIN SAMPLING AND ANALYSES}

For leptin analyses in studies III and IV maternal blood was collected in a test tube with a clot activator and gel for plasma separation. Within one hour after sampling, the blood was centrifuged and aliquoted and the plasma was stored at -70 degrees Celsius in the local biobank (register number 185, at the department of Obstetrics and Gynecology, Östergötland County Council) until further analyses.

The plasma leptin concentration was obtained using a direct sandwichbased ELISA (Enzyme-Linked ImmunoSorbent Assay) in studies III and IV. This method measures the antigen concentration in an unknown sample. The antigen of interest is quantified between two layers of antibodies: the capture and the detection antibody. These antibodies must bind to nonoverlapping epitopes on the antigen. An enzyme is used to convert a sub- 
strate to a product that may be detected, typically with quantitative colorimetric methods (Figure 7). This ELISA method for the detection and measurement of leptin levels in human plasma is now routine with available assays commercially available (78).

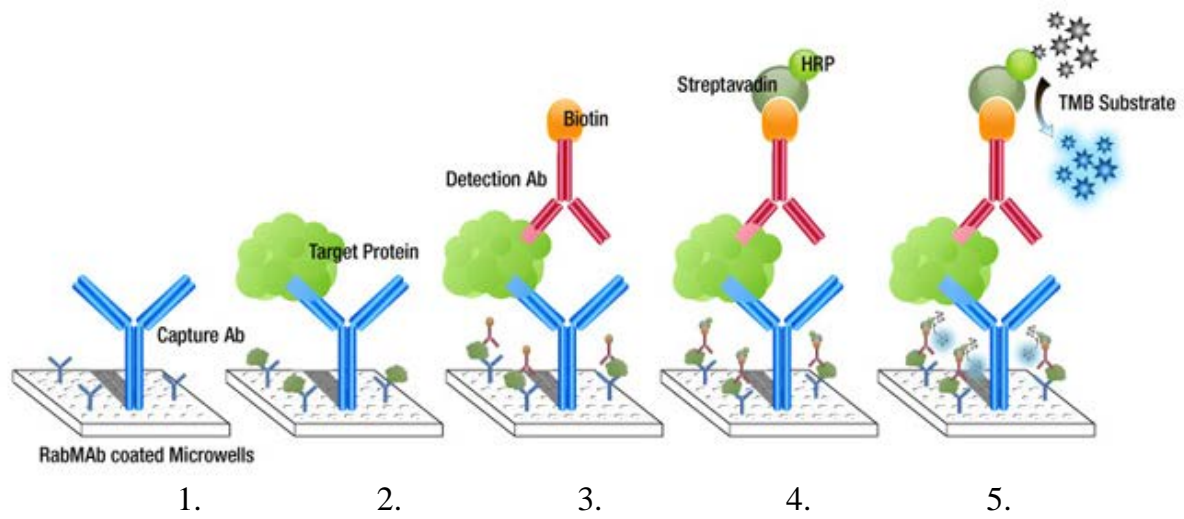

Figure 7. Direct sandwich based-ELISA method

Teuscher, N. (2014, July 7). Ligand Binding Assays [Sandwich assay]. Retrieved April 3, 2018, from https://www.certara.com/2014/07/22/ligand-binding-assays/

1. Microwell plate is coated with a capture antibody.

2. Maternal plasma is added to the plate and the human leptin in the plasma-sample binds to the capture antibody.

3. A detection antibody (monoclonal biotinylated antibody) is added to the plate and binds to the captured human leptin.

4. Streptavidin-horseradish peroxidase is subsequently added and binds to the immobilized biotinylated antibodies.

5. TMB (tetramethylbenzidine) substrate is added in the final step and converted to a detectable colored form.

The enzyme activity was spectrophotometrically measured after the acidification of the sample products terminated the enzymatic reaction.

In between each step, the wells were washed three to five times to eliminate unbound material. As increased absorbance is directly proportional to the amount of captured human leptin in unknown samples, quantification of human leptin may be derived from a generated reference curve with reference calibrators of known concentrations of human leptin. 


\section{STATISTICS}

\section{Descriptive statistics}

In studies I-III, the mean and standard deviation (SD) were presented for continuous variables and numbers and percentages were presented for categorical variables. Chi-square tests were performed to analyze descriptive frequency data, whereas one-way analyses of variance (ANOVA) were conducted to compare descriptive, continuous, normally distributed data over the BMI-classes.

In study IV, the leptin levels were not normally distributed and were therefore presented as medians and percentiles.

\section{Analyses of outcomes}

\section{Studies I, II and IV}

The outcome duration of active labor in study I was normally distributed. All other outcome parameters (durations of different phases of labor) were not normally distributed; however the logarithmic values were normally distributed.

To compare the differences in the mean labor duration between the BMI classes in studies I and II, one-way ANOVAs were employed. When the outcome parameters were not normally distributed, the logarithmic values were used or the Kruskal-Wallis non-parametric tests were performed to compare distributions between BMI groups. Analyses of covariance (ANCOVAs) were used to control for possible confounders.

To evaluate the relationships among the outcome, duration of labor, and BMI and/or leptin, survival analyses were employed. The reason for using these methods was to be able to include the duration of labors ending in CSs in the analyses. Survival analyses are often used to investigate the time to an event. In our studies, the event was defined as the end of each phase or stage of labor that was analyzed (i.e., birth or end of the active phase of labor). We used the Kaplan-Meier method and the Cox regression method in the analyses in studies I, II and IV. The Kaplan-Meier method is a descriptive method of the "survival process" that may also be used to compare the time to an event between several groups. However, it is not possible to analyze the effect of different covariates on the time to an event with the Kaplan-Meier method. The cox regression method is the most common survival analysis method to compare the time to an event between groups, as well as investigate how different covariates influence the survival-time. Censoring was performed in our survival analyses, for the women who had a cesarean delivery during the active phase. 
In study IV, the associations between the outcome (duration of the active phase of labor) and maternal leptin levels were also investigated with univariate and multiple linear regression analyses. Multiple linear regression analysis is used to analyze several variables to determine whether one or more variables are predictive of a certain outcome. Multiple imputations were used to address missing information on GWG in the statistical analyses, which included GWG as a potential confounding factor. This is a common method to handle missing values. As the amount of missing data was substantial we included 20 imputed data sets.

Potential confounders were included in the adjusted analyses in studies I, II and IV. In study I, maternal age and birth weight and year of delivery were included as confounders. In study II, ANCOVA was used to identify and control for confounders when evaluating differences in mean labor duration over BMI-groups. Only factors with a p-value $<0.2$ were included in the final analyses (maternal age, GWG, birth weight and vaginal delivery). Moreover in study II, when analyzing the relationship between the duration of labor and BMI, the confounders were identified with cox regression analyses as single independent factors that influenced the time in labor with a p-value $<0.2$. Maternal age, birth weight, smoking and GWG were included as confounding factors in the analyses on active labor. Birth weight and GWG were included as confounding factors in the analyses on latent labor. In study IV, univariate and multiple linear regression analyses were used to identify and control for confounders when analyzing the association between the duration of labor and leptin. The first multivariable model included leptin levels and variables considered possible confounding factors with $\mathrm{p}<0.2$ in the univariate analyses and the final restricted multivariable model included leptin levels and variables with $\mathrm{p}<0.2$ in the first full multivariable model. Parity, gestational age, induction, epidural anesthesia, oxytocin, birth-weight and leptin were included in the final multivariable model.

\section{Study III}

The outcome parameters, maternal leptin levels, were normally distributed. A two-way ANOVA model was used to analyze the mean value and confidence interval of maternal plasma-leptin in women with obesity class (I-III) and the different GWG groups (Bonferroni adjusted for multiple comparisons within each gestational week). Only BMI and GWG were included in the final model. No significant interaction effect between maternal BMI and GWG was identified (tested with a two-way ANOVA model). Therefore the analyses on leptin and GWG group were not adjusted for BMI and vice versa. No significant confounder was identified using general linear models to assess the possible confounding effects of smoking, GDM and $\mathrm{PE}$, in addition to the main effect model of BMI and GWG. 
For study I, the statistical software Gauss (GaussTM, Aptech Systems Inc., Maple Valley, WA, USA) (http://www.aptech.com) was used. The statistical software IBM SPSS version 23 (IBM, Inc., Armonk, NY, USA) was used for statistical analyses in studies II-IV. A p-value $<0.05$ was considered statistically significant.

\section{ETHICAL APPROVAL AND CONSIDERATIONS}

The studies in this thesis were approved by the Regional Ethical Review board in Linköping (Study I; Dnr M44-09, study II; Dnr 2017/274-31, study III; Dnr 2010/296-31 and Dnr 2013/378-32 and study IV; Dnr 03231.

Studies I and II were performed without the participants' informed consent. In research on personal health with data maintained in large registers informed consent is typically not required. The Personal Data Act (1998) aims to prevent the violation of personal integrity in the processing of personal data. Before treatment of sensitive personal data, such as health data, can be conducted, permission by a regional ethical review board is required. The ethical board can decide whether data from large registers may be accessed for research without informed consent. Inclusion of data in the Swedish Pregnancy Register does not require consent from the patients and participation in the register is voluntary. After ethical approval and application to register holders of the Swedish Pregnancy Register and PRS register, data were retrieved unidentified.

Written informed consent was obtained from all study subjects included in studies III and IV. The patients had the right to withdraw their consent at any time. The maternal blood samples used in studies III and IV were handled according to the Swedish Act Biobanks in Medical Care_(SFS 2002:297). The samples were coded, and the key code to the personal identity number is securely maintained at Region Östergötland. All leptin analyses were performed on coded plasma samples. The key code was used to identify the patients in the EMR. 


\section{RESULTS}

\section{DURATION OF LABOR AND BODY MASS INDEX (studies I and II)}

\section{Main findings of study I}

In the study population of 63,829 nulliparous women with a spontaneous start of labor, the duration of active labor significantly increased with increasing maternal pre-pregnancy BMI, illustrated with survival curves from the Kaplan-Meier analysis ( $p=0.038$ ) (Figure 8). The mean duration of the active labor increased with a higher BMI class from 8.8 hours in normal weight women to 9.8 hours in women with a BMI $\geq 40$. In 57,500 of the women, the median time in the pushing phase decreased with an increasing maternal pre-pregnancy BMI from 0.55 hours in normal weight women to 0.45 hours in morbidly obese women. The active labor durations were normally distributed. The second stage durations were not normally distributed; however the logarithmic values were normally distributed. The differences between the BMI categories in both mean active and log second stage durations remained significant when adjusting for maternal age and birth weight $(\mathrm{p}<0.001)$.

\section{Main findings of study II}

In nulliparous women with IOL, we determined that the durations of both the latent and active labor increased with maternal early pregnancy BMI; however the differences between the BMI categories were more pronounced in latent labor, illustrated with survival curves from the cox regression analyses (Figures 9 and 10).

Overweight women and women in obesity classes I-II who reached the active phase of labor had similar durations of active labor as normal weight women and a similar chance for a normal vaginal delivery. 


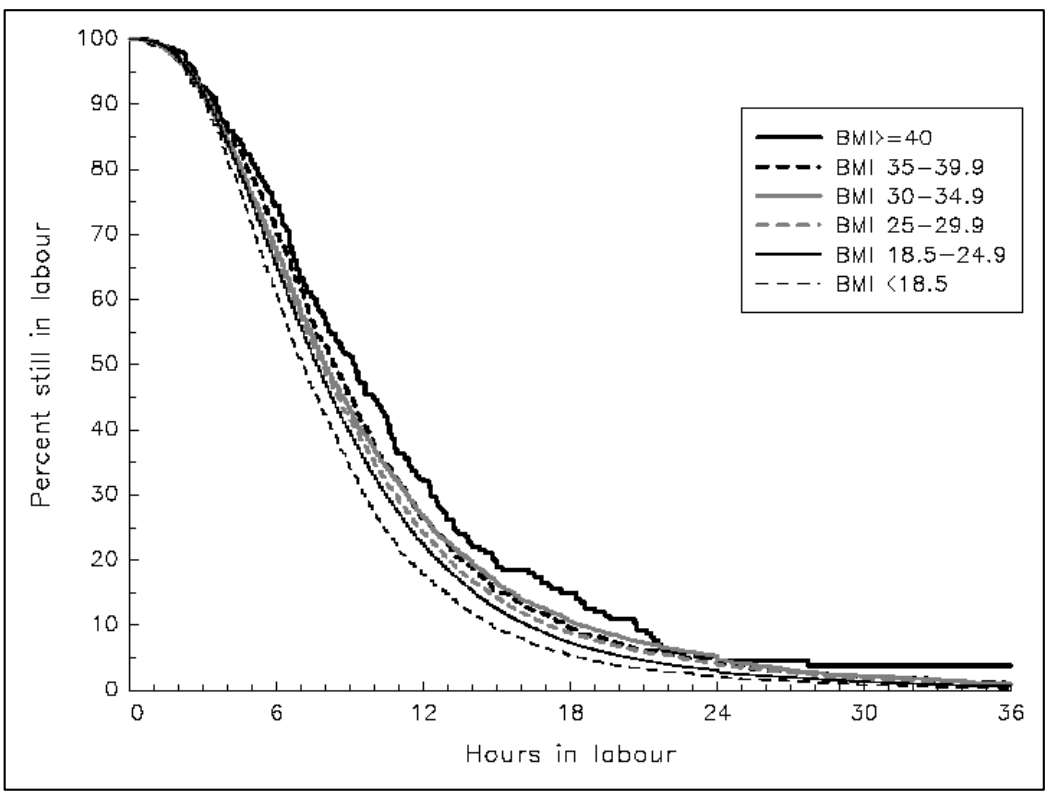

Figure 8. Duration of labor (hours) in nulliparous women with a spontaneous onset of labor in relation to their BMI. Women were censored at the time of emergency caesarean section. $\mathrm{P}$ for difference between groups $=0.038$.

\section{Median labor duration in studies I and II}

The median duration of latent labor and active spontaneous labor successively increased with maternal BMI. Underweight women had a shorter median duration of active labor (both spontaneous and induced labor) than women in other BMI classes (Table 4). The durations of the latent and active induced labor were not normally distributed; however the logarithmic values were normally distributed and were used to explore differences between the BMI categories. The differences were significant when adjusted for confounding factors. 
Table 4. Median duration of labor in nulliparous women with a spontaneous onset of labor or induction of labor.

\begin{tabular}{|l|l|l|l|c|l|c|}
\hline $\begin{array}{l}\text { Maternal } \\
\text { Body Mass } \\
\text { Index } \\
\left(\mathbf{k g} / \mathbf{m}^{2}\right)\end{array}$ & \multicolumn{2}{|l|}{$\begin{array}{l}\text { Time in latent induced } \\
\text { labor (hours). } \\
\mathrm{N}=15,073\end{array}$} & \multicolumn{2}{l|}{$\begin{array}{l}\text { Time in active induced } \\
\text { labor (hours). } \\
\mathrm{N}=15,259\end{array}$} & \multicolumn{2}{l|}{$\begin{array}{l}\text { Time in active sponta- } \\
\text { neous labor (hours). } \\
\text { N=63,829 }\end{array}$} \\
\cline { 2 - 7 } & $\mathrm{N}(\%)$ & Median & $\mathrm{N}(\%)$ & Median & $\mathrm{N}(\%)$ & Median \\
\hline$<18.5$ & $322(2.1)$ & 12.9 & $325(2.1)$ & 6.1 & $2,024(3.2)$ & 7.05 \\
\hline $18.5-24.9$ & $8,434(56.0)$ & 14.5 & $8,509(55.8)$ & 7.4 & $43,052(67.4)$ & 7.53 \\
\hline $25-29.9$ & $3,993(26.5)$ & 16.3 & $4,044(26.5)$ & 7.6 & $13,823(21.7)$ & 7.70 \\
\hline $30-34.9$ & $1,568(10.4)$ & 18.2 & $1,605(10.5)$ & 7.6 & $3,641(5.7)$ & 7.75 \\
\hline $35-39.9$ & $549(3.6)$ & 21.0 & $562(3.7)$ & 7.0 & $988(1.5)$ & 8.08 \\
\hline$\geq 40$ & $207(1.4)$ & 22.6 & $214(1.4)$ & 7.4 & $301(0.5)$ & 8.45 \\
\hline
\end{tabular}

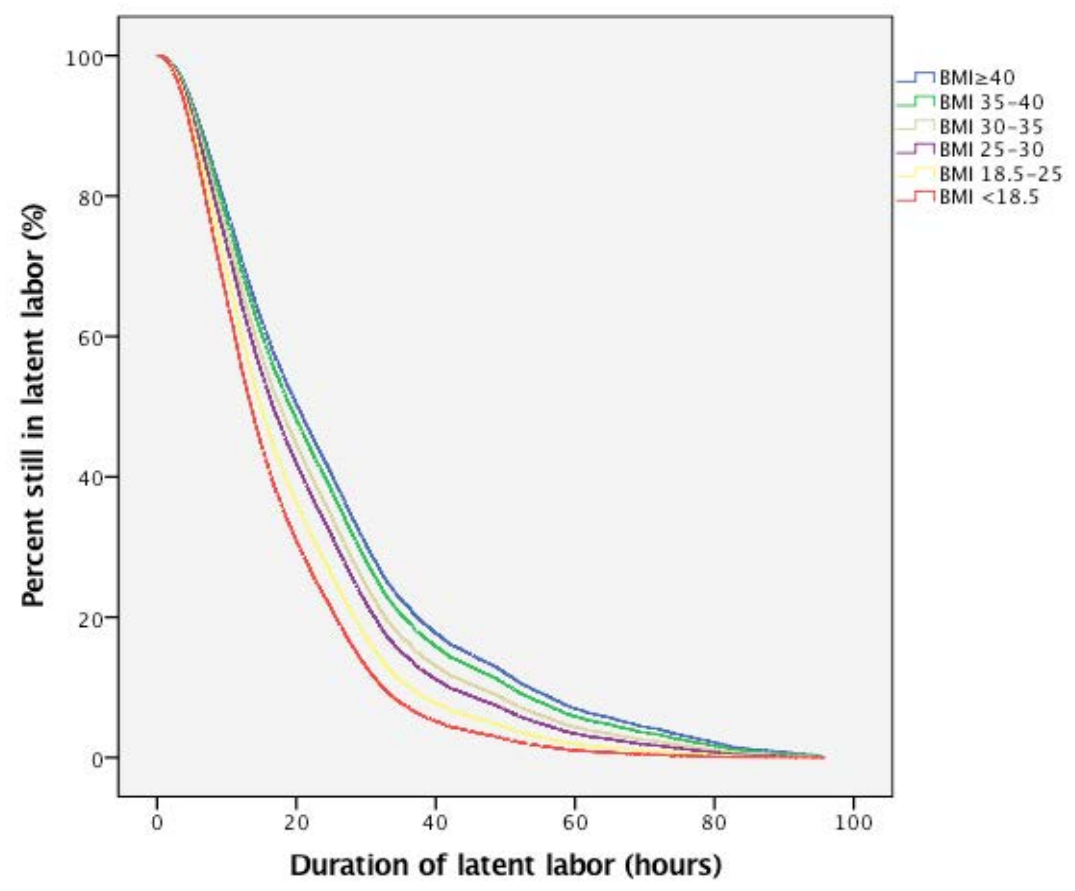

Figure 9. Survival curves illustrating time in latent labor in nulliparous women with IOL in relation to maternal early pregnancy BMI. Latent labor was defined as the time from admission for IOL until the start of active labor. Event was defined as entering active labor. Adjustments were made for birth weight and GWG. P for difference between BMI-groups $<0.001$. 


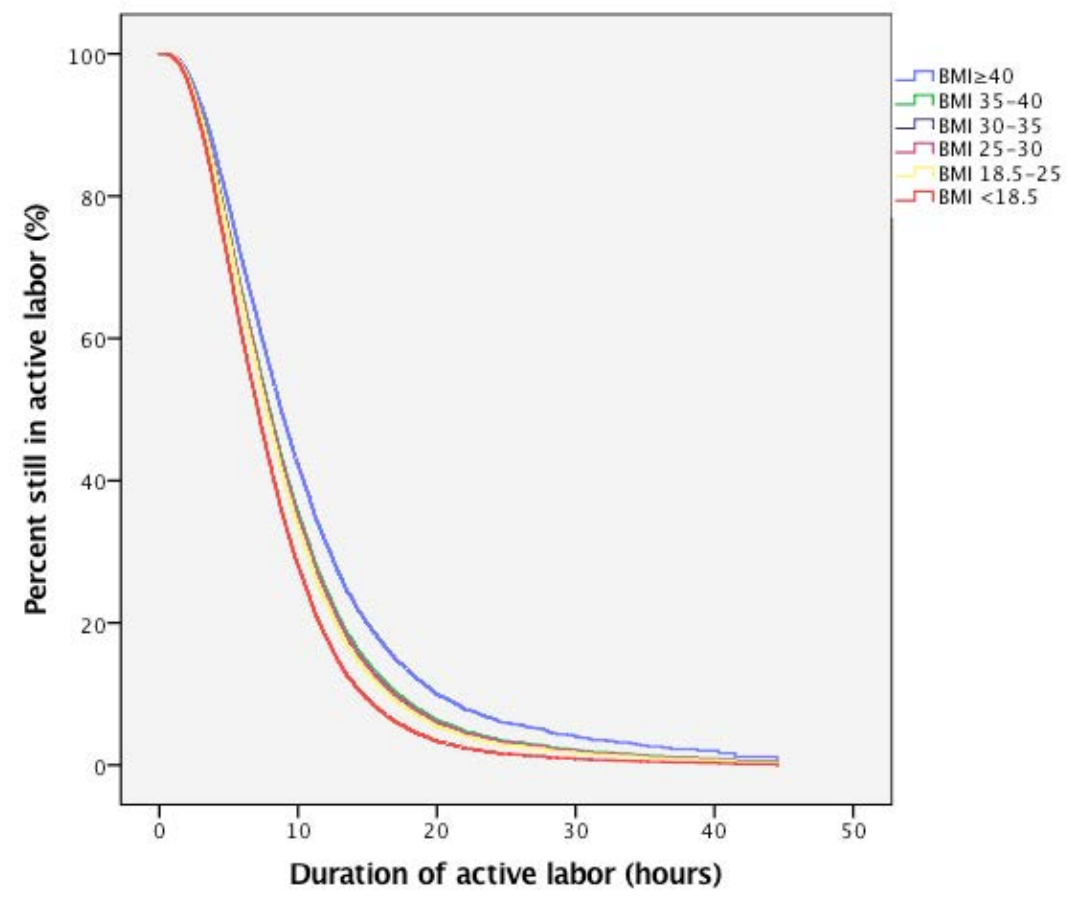

Figure 10. Survival curves illustrating time in active labor in nulliparous women with IOL in relation to maternal early pregnancy BMI. Active labor was defined from the onset of regular painful contractions and cervical dilatation $\geq 3 \mathrm{~cm}$ until the time of delivery. Event was defined as delivery. Women were censored at the time of CS. Adjustments were made for maternal age, birth weight, GWG and smoking in early pregnancy. P for difference between BMI-groups $<0.001$. 


\section{MATERNAL AND LABOR CHARACTERISTICS, MODE OF DELIVERY AND BODY MASS INDEX (studies I and II)}

The prevalence of obesity in the study population in studies I and II differed. In the study population in study I, conducted between 1995 and 2009, the prevalence of overweight was $21.7 \%$ and $7.7 \%$ were obese, compared to $26.5 \%$ with overweight and $15.6 \%$ with obesity in study II, conducted between 2014 and 2017. The mothers were older in study II; $15.9 \%$ of women were older than 35 years compared to $7.9 \%$ in study $\mathbf{I}$. Birth weight increased with BMI in both studies. The rate of infants with a birth weight $\geq 4500$ g was higher in study II (4.2\%) than in study I (2.2\%).

In study I, oxytocin for augmentation was administered to $45.0 \%$ of normal weight women and $55.1 \%$ of women in obesity class III ( $p<0.001)$. The reported rate of oxytocin usage in induced labor in study II was similar in normal weight and obese women (Figure 11).

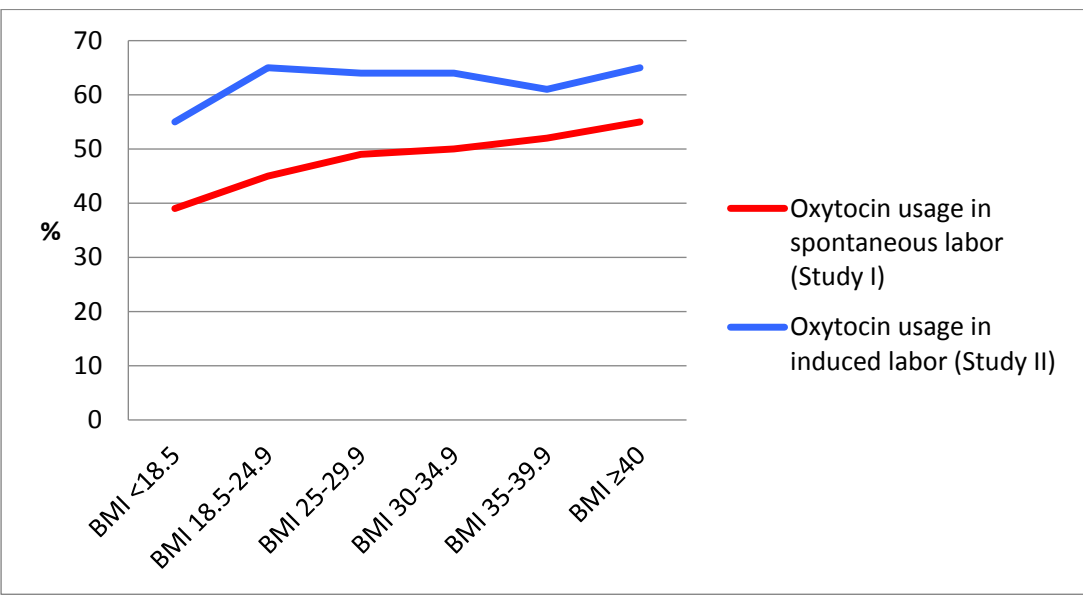

Figure 11. The reported rates of oxytocin usage in the different BMI categories in study I and study II.

The prevalence of CS in the population of women with a spontaneous onset of labor was $6.0 \%$ (study I) compared with $15.5 \%$ in the population of women with IOL (study II). The CS rates during the active phase of labor successively increased with BMI in nulliparous women with a spontaneous onset of labor (study I) and women with induced labor (study II) and, in general, were higher in women with induced labors. In study I, the CS rate was $5.1 \%$ in normal weight women compared to $15.6 \%$ in women in obesi- 
ty class III ( $\mathrm{p}<0.001)$. In study II, the CS rate significantly increased from $7.4 \%$ in underweight women (13.5\% in normal weight women) to $22.0 \%$ in women in obesity class III ( $\mathrm{p}<0.001)$. In study II, the rate of operative vaginal delivery was lower in all obesity classes compared to normal weight women with IOL ( $p$ for homogeneity $<0.001$ ). This trend was not identified in women with spontaneous labor (study I). Figures 12 and 13 illustrate the mode of delivery in the different populations in studies $\mathbf{I}$ and II.

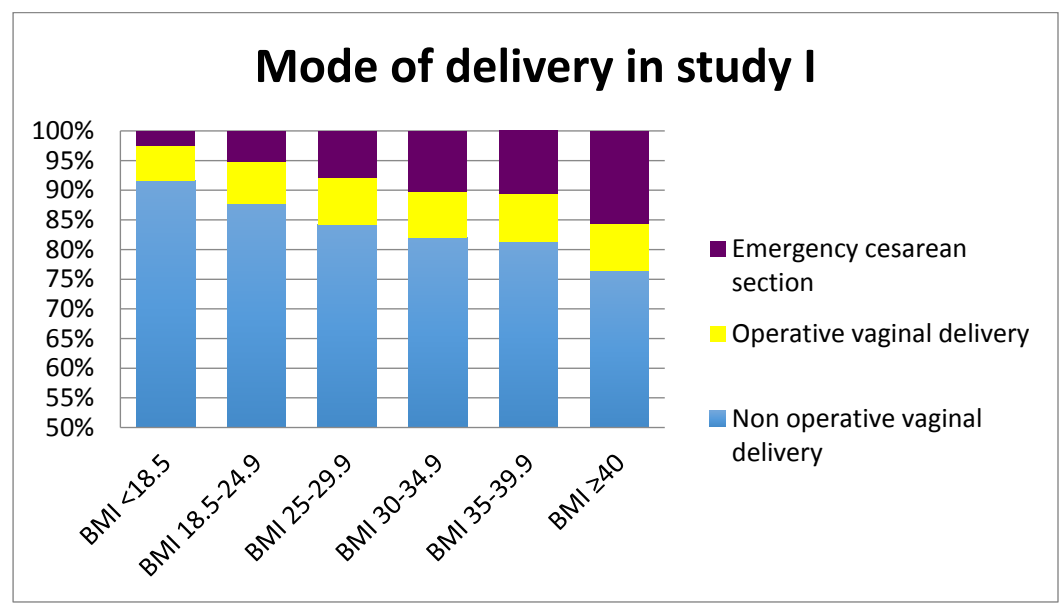

Figure 12. Mode of delivery in women with spontaneous onset of labor.

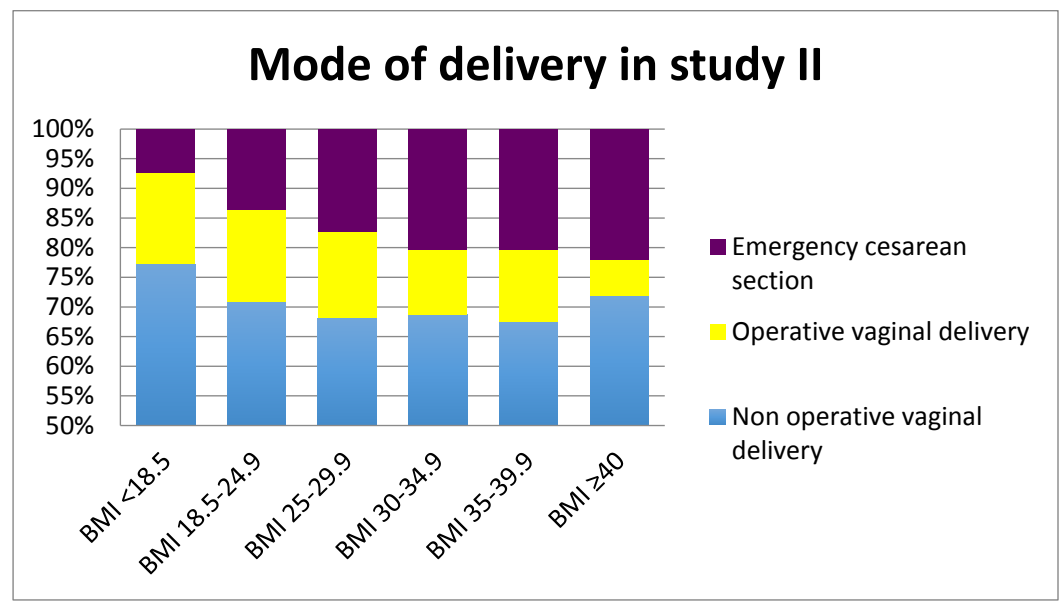

Figure 13. Mode of delivery in women with induced labor. 


\section{MATERNAL LEPTIN LEVELS IN OBESE WOMEN (study III)}

\section{Main findings}

The mean maternal plasma leptin concentrations during and after pregnancy appear to be associated with the degree of maternal obesity but not with the degree of GWG. In the study population of 343 women with early pregnancy obesity, the mean maternal leptin levels were significantly higher during and after pregnancy in women with obesity class III than women with obesity class I. No major differences in the maternal leptin levels were identified during or after pregnancy between the obese women when they were classified into groups according to the degree of GWG based on the recommendations from the IOM (Table 2).

\section{Maternal characteristics and classification}

The study population was classified according to the degree of obesity classes I-III ( $n=343$ ), and the degree of GWG during pregnancy based on the recommendations of the American IOM for obese pregnant women i.e., below, recommended or above recommendations $(n=304)$ (Figure 14).

The mean GWG was significantly lower in women with obesity class III $(7.7 \mathrm{~kg})$ than classes I $(10.6 \mathrm{~kg})$ and II $(9.6 \mathrm{~kg})$. The prevalence of PE increased with a higher obesity class, with $5.4 \%$ in obesity class I compared to $18.6 \%$ in obesity class III. The rate of GDM did not differ between obesity classes I-III.

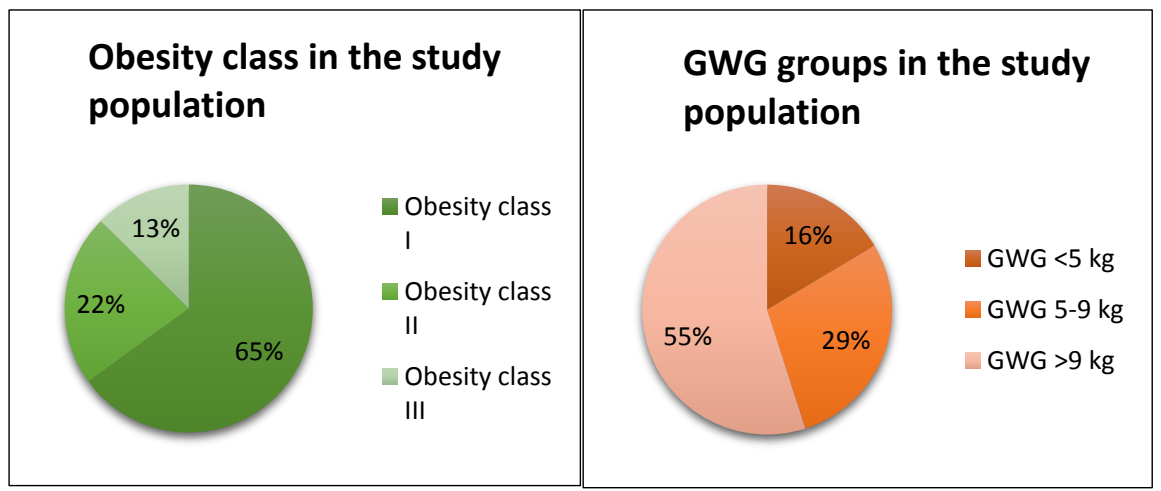

Figure 14. Classification of the study population in study III 


\section{Leptin levels}

Maternal plasma leptin was measured in gestational week $15(n=340)$, gestational week $29(n=331)$ and 10 weeks postpartum $(n=295)$. There was no significant correlation between the gestational week when the maternal plasma sampling was performed and the value of leptin within each timeperiod of leptin measurement. No significant interaction between maternal BMI and GWG was identified. Figure 15 demonstrates the mean plasma leptin values in the different obesity classes. The differences in the mean value were significant between all categories with the exception of women with obesity classes I and II in gestational week 29 and classes II and III postpartum. Figure 16 demonstrates the mean plasma leptin values in the different GWG classes. The degree of GWG in obese women did not have a significant effect on the mean plasma leptin values with the exception of gestational week 29 when obese women with a weight gain above recommendations (>9 kg) had significantly higher values than women with the recommended GWG (5-9 kg).

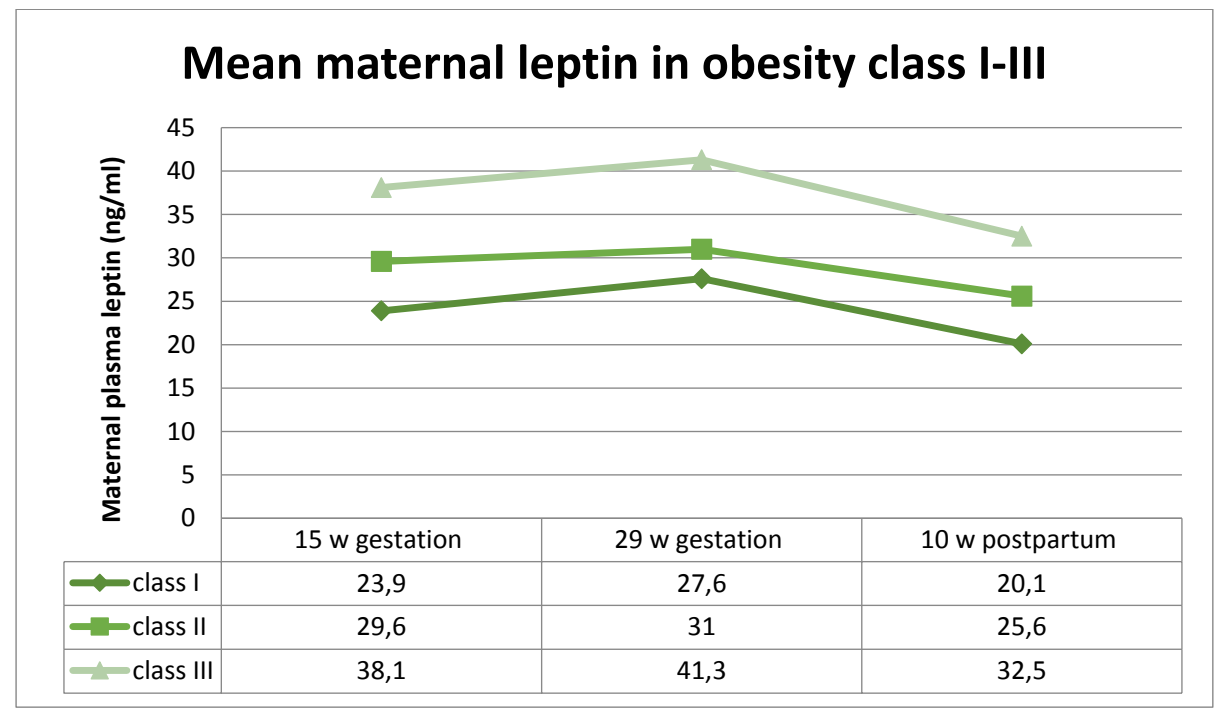

Figure 15. Mean maternal plasma leptin $(\mathrm{ng} / \mathrm{ml})$ during and after pregnancy in obesity classes I-III. ( $w$ = weeks) 


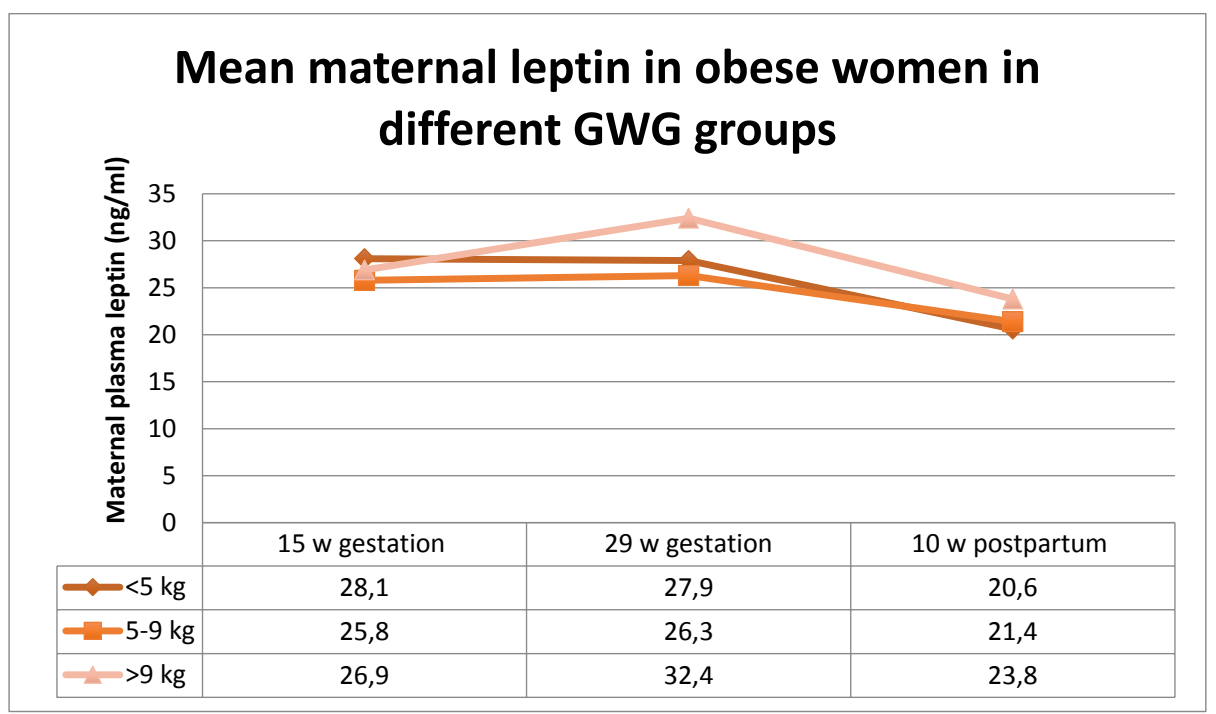

Figure 16. Mean maternal plasma leptin (ng/ml) during and after pregnancy in obese women classified according to degree of GWG. $(w$ = weeks)

\section{MATERNAL LEPTIN AND DURATION OF LABOR (study IV)}

\section{Main findings}

In this study of 914 women, we did not identify a statistically significant association between the maternal plasma leptin levels measured in active labor and the duration of the active phase of labor. Positive associations between increasing maternal leptin levels and a longer time in the active phase of labor in the total study population and women with a spontaneous onset of labor $(n=766)$ were identified in the unadjusted analyses. In the unadjusted analyses, a one $\mathrm{ng} / \mathrm{ml}$ increase in maternal plasma leptin was associated with a 0.015 hour increase in the duration of the active phase of labor $(\mathrm{p}<0.007)$ in the total study population. In women with a BMI $\geq 35$, the median leptin value was $50 \mathrm{mg} / \mathrm{ml}$, which would indicate that the time in the active phase of labor increased with 0.75 hours. This association was not statistically significant when adjusted for confounding factors or when nulliparous and multiparous women were analyzed separately. 


\section{Maternal characteristics and leptin levels}

The prevalence of obesity was low in the study population; $6.7 \%$ of women were obesity class I, and $2.1 \%$ of women had an early pregnancy BMI $\geq$ 35. Moreover $2.1 \%$ of women were diagnosed with PE, and $1.3 \%$ of women were diagnosed with GDM. As all women with an unknown start of active labor and start of the pushing phase were excluded (67 women), women with CS during the active phase of labor were thus excluded. Moreover, $72 \%$ of women had information on GWG and these women were categorized in three classes of GWG, i.e., below recommended, recommended or excessive weight gain, based on the IOM guidelines on weight gain during pregnancy, in relation to pre-pregnancy BMI (Table 2).

The median leptin values were higher with increasing BMI class (20.2 $\mathrm{ng} / \mathrm{ml}$ in normal weight compared to $50.0 \mathrm{ng} / \mathrm{ml}$ in women with a BMI $\geq$ 35). The median leptin value was also higher with an increasing degree of GWG. Women with a GWG below the recommendation had a mean leptin of $16.4 \mathrm{ng} / \mathrm{ml}$ compared to $33.0 \mathrm{ng} / \mathrm{ml}$ in women with a GWG above the recommendations. Women with PE or GDM had a higher leptin value than their counterparts.

\section{Maternal leptin, duration of labor and maternal BMI}

The association among maternal leptin, time in labor and maternal BMI was analyzed with a Kaplan-Meier analysis. The study population was categorized in four groups based on the maternal BMI and mean leptin levels. Two groups included normal weight and underweight women with mean leptin levels above $(\geq 37 \mathrm{ng} / \mathrm{ml})$ or below $(<37 \mathrm{ng} / \mathrm{ml})$ the third quartile and two groups included overweight and obese women with mean leptin levels above $(\geq 37 \mathrm{ng} / \mathrm{ml}$ ) or below $(<37 \mathrm{ng} / \mathrm{ml})$ the third quartile. The relationship between the groups and the time in labor is presented in Figure 17. This Kaplan-Meier graph, illustrates the cumulative chance to end the active phase of labor at a certain time point by the maternal BMI category and leptin value in active labor. There was no overall statistically significant difference between the groups $(\mathrm{p}=0.296)$. However, the figure indicates a difference between the groups after a 10 hours duration of labor when normal weight/underweight women with lower leptin levels (below the third quartile/ $<37 \mathrm{ng} / \mathrm{ml}$ ) had a greater chance to end the active phase of labor at a given time point than overweight/obese women with high leptin levels $(\geq 37 \mathrm{ng} / \mathrm{ml})$. 


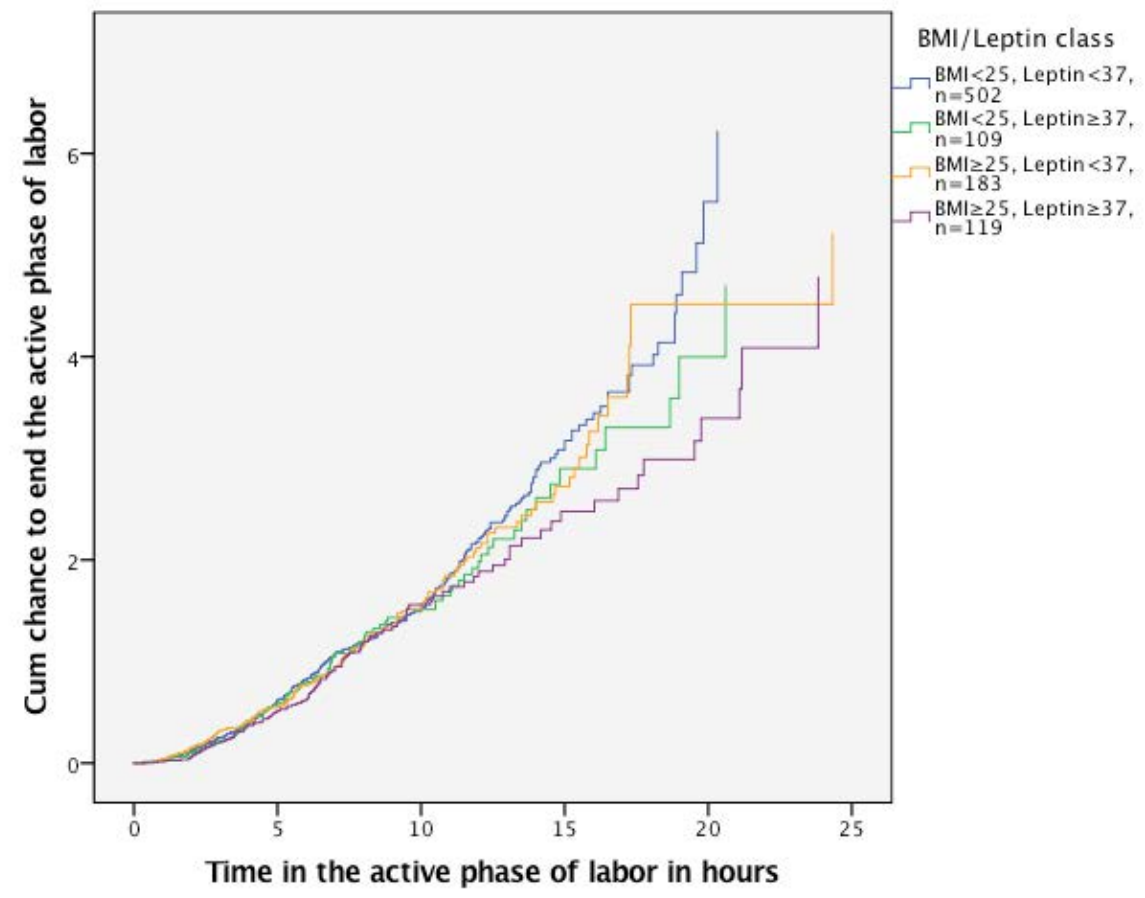

Figure 17. Kaplan Meier graph illustrating the association between leptin levels, maternal BMI and duration of labor ( $P$ for difference between groups $=\mathbf{0 . 2 9 6}$ ). 


\section{DISCUSSION}

\section{METHODOLOGICAL DISCUSSION}

All four studies included in this thesis are designed as observational cohort studies. This type of study design evaluates the association between an exposure and specific outcomes. The use of previously collected data accessible in registers in observational studies may be an alternative to reduce the risk of associated disadvantages with this study design, such as a long study duration and substantial costs. All data obtained in the studies included in this thesis are prospectively collected in the PRS register, Swedish Pregnancy Register or in EMR/Obstetrix ${ }^{\circledR}$. The large sizes of the study cohorts in study I and study II enabled us to restrict our analyses to nulliparous women and to evaluate the time in labor according to six maternal BMI classes, including three obesity classes. A major disadvantage when using previously collected data in registers is that the information on exposures and outcomes is limited to the information that is available in the registers. In studies I, II and IV we defined the different phases of labor according to the available time estimates on labor in the PRS register, Swedish Pregnancy Register and EMR/Obstetrix ${ }^{\circledR}$. We initially aimed to analyze the active phase of labor in study II, defined as in study IV. However, during the analyses, we discovered that the variable "start of pushing contractions" was incorrect and was not usable in the Swedish Pregnancy Register. This issue may be a result of an error in the data extraction programme to this new register.

In observational cohort studies, the internal validity, i.e., the degree to which the results of a study are correct for the specific study patients included, is affected by systematic errors (bias) and random errors (chance). Large study populations reduce the risk of random errors; however systematic errors (bias) are not affected by sample size. There are three types of bias that are always present to some degree in observational studies: selection bias, information bias and confounding bias (100).

Selection bias occurs when comparisons are performed between groups that differ in other ways than the outcome of the study, if these factors also affect the outcome. In studies I, II and IV, when labor duration was the main outcome, we attempted to reduce the risk of selection bias by restricting the inclusion criteria to nulliparous women, because the active phase of 
labor is shorter in multiparous women (30). Furthermore, we chose to independently investigate labor that started spontaneously and inductions in studies I and II, because it has been demonstrated that duration and progress differ between spontaneous and induced labors $(72,73)$. We decided to include women with emergency CS in studies I and II but not in study IV. This decision was related to the exposure. As the exposure was maternal BMI in studies I and II and it is well established that the CS rate increases with an increasing BMI, the exclusion of CS deliveries could have resulted in a selection bias if many of the CSs were performed after a long trial of labor. In study IV, the time in labor was not related to maternal BMI and was considered a clinical proxy for myometrial contractility. If emergency CSs were included and most CSs were performed as a result of fetal distress this could have introduced a selection bias. Moreover, if most CSs were performed due to dystocia/no progress, their exclusion may have also caused a selection bias. There was no information on the indication for CS; thus, we chose to include only those who had information on and reached the second stage. Furthermore, in study IV, the study population was restricted to women who agreed to participate in GRABB and may not be representative of the total population. The fact that few obese women were included may be a source of selection bias, if the exposure (the maternal leptin-value) causes a dose-response related effect on the time in labor because the obese women had high mean leptin values.

Information/Misclassification bias occurs when information used in a study is measured or recorded inaccurately. The data obtained from the registers or medical records were prospectively recorded, thus diminishing the risk of recall bias. In large registers there is always a risk of underreporting variables. One example is the registration of oxytocin for induction/augmentation in the Swedish Pregnancy Register (study II). The use of oxytocin is either automatically transferred from the partogram or manually registered. There is no reason to suspect that the degree of underreporting varies over the BMI classes. Information bias may result from misreporting by study participants. In study I, we used self-reported prepregnancy or measured early pregnancy BMI. Although previous studies have shown that self-reported BMI is reliable, $(101,102)$ it may be a potential source of bias. The self-reported pre-pregnancy BMI or early pregnancy BMI employed in studies I-IV is preferred to maternal BMI based on weight at delivery. The use of maternal BMI at delivery may cause a misclassification bias as most obesity related risks are related to pre-/early pregnancy BMI. Later in pregnancy, not only the maternal fat mass but also the amount of GWG, birth weight, placental weight and amniotic fluid will contribute to affect maternal BMI. In studies I, II and IV, the estimations of the parameters that underlie how the labor phases are defined are based 
on subjective measurements and are therefore not uniform across the study population. However, in large study populations, the variation of the estimation is not likely related to the outcome and the risk of a differential misclassification between the BMI-groups or that the variation should be related to the maternal leptin value is likely low. The use of time at admission for IOL as a proxy for the actual start of induction in study II is a limitation that may have led to a differential misclassification of the start of latent labor according to maternal BMI. The time difference from admission to the start of induction is not likely related to maternal BMI for most women. However, some women may have been admitted because of a pregnancy complication and observed for a period of time before IOL started. As obese women are at a higher risk for pregnancy complications, such as PE and GDM, which may lead to IOL, there is a risk that this possible misclassification was related to maternal BMI. In an attempt to reduce this risk, women with time estimates that were considered to be incorrect (time from admission until the start of active labor $<30$ minutes or $>96$ hours) were excluded. Information bias may also occur in objective measurements, such as the leptin analyses. To reduce this risk in studies III and IV, one trained individual performed the analyses with standardized methods in the same laboratory.

Confounding bias occurs when there is a failure to adjust for common causes of both the exposure and the outcome. A confounder is not on the causal pathway between the exposure and the outcome; thus in this case it is an intermediate variable, which should not be adjusted for in analyses. Adjusting for factors that are not confounders may introduce bias instead of removing it (103). True and known confounders should be controlled for in analyses. In studies I and II, the study population was restricted to nulliparous women to rule out the effect of parity. Maternal age and birth weight were regarded as confounders in these two studies. In study I we did not adjust for other factors, as they were regarded as intermediate variables. In study II, we analyzed each possible confounder, and only the variables that had some association with the outcome were included in the final multivariable regression analyses and cox regression analyses. In study III, possible confounders were analyzed with regression analyses; however, no significant interactions were found and no factors were included as confounders in the final analyses. In study IV, the study population was stratified into subgroups to eliminate the potential confounding effect of parity and induction. In this study, it was more difficult to determine which variables were true confounders because there was no previous study to compare with and the knowledge on labor and birth related factors in relation to maternal leptin is limited. The final multivariable regression model included 
only the factors that had an association with the duration of labor in the univariate and full multivariable model.

External validity is the degree to which the results may be applied to other individuals and settings, i.e., the generalizability of the study. As study I and study II are large cohorts, the results from these studies are generalizable to the Swedish population or similar populations and settings. The results are not generalizable to other populations and countries that have different definitions for the start of the active phase of labor and where the clinical management of laboring women to promote a spontaneous vaginal delivery may differ. Furthermore, when specifically analyzing the effect of maternal BMI, the substantial variations in the prevalence of obesity worldwide must be taken into account as this may limit the possibility to generalize the results of different studies to different populations. The low prevalence of obese women in the study population in study IV may explain why BMI was not associated with the duration of labor as in studies I and II and may have caused a biased sample that influenced the internal and external validity. The results of study III describe leptin levels in a demarcated group. This knowledge may provide information when investigating obese pregnant women in other settings.

Random errors are caused by variations in the data as a result of chance. Statistics may be used to estimate the extent to which chance accounts for the results in a study, i.e., significance testing. The role of random error may be presented as a p-value. In studies I-IV, a p-value of 0.05 was set as the significance level. This indicates the probability that the null hypothesis is true. If the p-value is low $(<0.05)$, the null hypothesis may be rejected. However, a low p-value does not indicate that the difference is of clinical importance. In large cohorts, such as in studies I and II, even small differences may be statistically significant but without clinical importance. The risk of random errors in cohort studies are reduced with large study cohorts and with dose-response associations between the exposure and the outcome, such as in studies I and II.

\section{DISCUSSION OF FINDINGS IN STUDIES I-IV AND CLINI- CAL IMPLICATIONS}

\section{Spontaneous onset of labor}

The study population in study I is one of the largest cohorts of nulliparous women with a spontaneous onset of labor in which the duration of labor has 
been analyzed. It is of substantial importance to understand the course of labor in this defined group because they constitute a substantial part of all laboring women. If a CS may be avoided among these women, the chances are great that their following deliveries will be normal and uncomplicated. The results of previous studies that demonstrated the time in labor increases with maternal BMI are difficult to compare because of the different definitions of maternal obesity and active labor employed and the inclusion of mixed parities with both spontaneous and induced labor onset (45, 49-51, 104). However, the results from our study support previous findings that the time in active labor significantly increases with maternal BMI. We determined that the duration of the pushing phase significantly decreased with an increasing maternal BMI. Although the difference in the duration of the pushing phase between obese and normal weight women was not of clinical importance, (6 minutes difference in the median value), it indicates that the prolongation of labor progression in obese women was restricted to the active phase of labor. The question of whether the statistically significant difference in the mean duration of active labor between the BMI groups is clinically meaningful may also be considered. The largest difference in the mean values was identified between underweight $(8.2 \mathrm{~h})$ and morbidly obese women $(9.8 \mathrm{~h})$, whereas the differences in the mean duration between other BMI classes were less. However, there were substantial variations within each BMI category. A similar time difference of mean duration between BMI classes was identified in a large American multicenter study (45). The main conclusion from study $\mathbf{I}$ is that obese women, particularly morbidly obese women, have a statistically and clinically significant increased risk for a longer duration of active labor compared to normal weight women. The general recommendations for diagnosing labor arrest are not defined according to BMI class. If obese women are allowed to be in active spontaneous labor for a longer time than the general recommendations, it may increase their chance to avoid a CS, which causes a major impact on future pregnancy outcomes.

\section{Induced labor}

Among previous research that addressed the specific impact of maternal BMI on labor progression, limited studies have been restricted to induced labors in nulliparous women and most studies are based on maternal BMI at labor admission $(45,59,67,68)$. We identified only one study that compared the latent and active phases of induced labor in relation to maternal early pregnancy BMI (71). The results from study II contribute knowledge regarding the duration of induced labor, both latent and active labor, in nulliparous women with respect to their early pregnancy BMI. As most women are risk-classified according to their early pregnancy BMI, this study provides important information from a national cohort where few women 
had an unknown BMI in early pregnancy (4.6\% of all nulliparous term women with IOL). The duration of induced labor increases with a higher maternal early pregnancy BMI. However, the survival curves that illustrated the duration of active labor were not visually different between normal weight, overweight and obesity classes I and II, in contrast to the survival curves from latent labor when the duration successively increased with BMI class. This finding is in contrast to the previous mentioned study that analyzed latent labor, in which no association was identified with maternal BMI; however, different definitions of the labor phases were employed (71). Our results on latent labor must be considered in light of the factors that may have biased the results. The use of the time at admission instead of the actual time when the induction started may have falsely prolonged the latent phase for some women who may have been observed after admission and before the initiation of the induction method. Furthermore, we were not able to adjust for cervical ripeness and we excluded women with CSs during the latent phase. As obese women, to a larger extent, have pregnancy complications that may lead to observation before IOL, more often have an unfavorable bishop score at induction and may be at a higher risk for a CS during the latent phase $(7,105)$, it is possible that the assessment of latent labor duration in obese women was biased. When interpreting the results and considering the limitations, there are two groups that stand out from the rest. The results on these groups constitute one of the most important messages from this study. First, women with morbid obesity (class III) constitute a risk group with longer durations of both the latent phase and active labor, with the highest rate of oxytocin and EDA usage and the highest risk for a cesarean delivery during active labor. Second, underweight women have substantially less risks than other BMI classes. They had shorter labor durations (latent and active labor), the lowest rate of EDA and oxytocin usage, the lowest rate of CS and the highest rate of normal vaginal delivery. This information is important to take into account when the pros and cons are considered in the clinical decision of whether a labor should be induced or not.

\section{Mode of delivery related to BMI}

The mode of delivery in relation to maternal BMI differs in the large cohorts analyzed in studies I and II. This finding is partially a result of the different nature of the study populations, i.e., spontaneous labor onset vs. IOL. It is shown that women with IOL have a greater risk for a cesarean delivery than women with a spontaneous onset of labor (OR 2.54-3.06 for CS in induced labor compared to spontaneous onset) (62, 63). This finding explains the different prevalence of CSs between the cohorts $(6.0 \%$ vs. $15.5 \%$, respectively). However, when considering women with a BMI $\geq 40$ with the highest CS rates, the difference between spontaneous and induced 
labor may not be as substantial as expected (15.6\% vs. $22.0 \%$, respectively). The time difference between when the studies were conducted may explain the lower difference in the CS rate in obese women. During this time span, the general knowledge of obesity related complications in pregnant women had increased. This knowledge may have led to obese women being handled in a better way to reduce the risk of CS in this group. This may also be reflected in the prevalence of normal vaginal delivery in morbidly obese women, which is approximately the same in the different cohorts $(76.4 \%$ in spontaneous labor vs. $72.0 \%$ in induced labors). When comparing the CS prevalence in study II with the results from older studies on nulliparous women with IOL, the total CS rate in our study is approximately half the size $(48,64,70)$. In study I, the CS rate increased proportionally with an increasing BMI, which reflected the same pattern as the labor duration in relation to BMI. This was not identified in study II, where the CS rate did not reflect the pattern of active labor duration in relation to BMI, which may indicate that there are other factors than a prolonged labor duration in induced women that contribute to the higher rate of CS in overweight and obese women.

\section{Leptin in obese women}

Previous studies indicate that leptin levels in overweight and obese women are elevated during pregnancy compared to normal weight women $(81,84)$. It has also been shown that the rate at which leptin levels increase across gestation is lower for obese/overweight women $(85,86)$ than normal weight women. Misra et al determined that these different patterns in leptin increase could not be fully explained by the lower GWG in overweight/obese women because the change in leptin/kg body weight increased in normal weight but decreased in over-weight/obese women, which suggests that factors other than GWG could influence leptin levels during pregnancy (85). To our knowledge study III is the first investigation to describe leptin levels during and after pregnancy in different obesity classes and contributes new knowledge on leptin profiles in obese pregnant women. Women with obesity class III had significantly higher mean leptin values at each leptin measurements than women with obesity class I. As no significant interaction effect was identified between BMI and GWG, these parameters were not included as confounders in the analyses. When the mean leptin values were analyzed according to the degree of GWG, no significant changes were identified. To evaluate the full effect of GWG, a leptin measurement in late pregnancy would have been valuable. However, in this study it appears that leptin levels in obese women during and after pregnancy are associated with pre-pregnancy BMI but not the degree of GWG. 
In the study population, the prevalence of PE significantly increased with the degree of obesity. It has previously been shown that obesity associated pregnancy complications, such as PE and GDM, are associated with increasing maternal leptin levels, as well as an increasing degree of obesity $(80,89)$. If leptin is involved in the step-wise increased risk for several adverse outcomes, including a prolonged time in labor, with each increase in obesity class the leptin levels should reflect this increased risk. Our results contribute to knowledge regarding this issue by demonstrating significant differences in leptin levels between the maternal obesity classes.

\section{Leptin and duration of labor}

The results from study IV contribute new knowledge on an issue that has previously only has been analyzed in in vitro settings. This investigation is the first study to analyze the association between maternal leptin levels measured in active labor and the duration of the active phase of labor. We hypothesized that high leptin levels would correlate with a longer labor duration based on findings from in vitro studies. A reduced frequency and amplitude of contractions in myometrium from obese women compared to myometrium from normal weight women have been demonstrated in vitro (55). It has also been shown that leptin has an in vitro cumulative inhibitory effect on human myometrial contractions (spontaneous and oxytocin induced) $(92,94)$. The combination of these in vitro findings, the high leptin levels identified in obese pregnant women and the increased risk for a prolonged duration of labor led to our hypothesis. However, in our studypopulation, we did not identify a statistically significant association in the adjusted analyses between leptin levels and the duration of the active phase of labor. Our initial attempt was to investigate the effect of leptin on labor duration without classifying the study population based on maternal BMI. If leptin in vivo exhibits a similar dose-response effect on myometrial contractility as in vitro, it may not be possible to demonstrate this putative effect of leptin in a study population that includes a limited number of obese women. The results from this study should be considered a first attempt to investigate the clinical effect of leptin on myometrial contractility and encourage future studies to assess this effect in obese women compared to normal weight women. 


\section{CONCLUSIONS}

Based on the studies included in this thesis the following conclusions may be drawn:

- The duration of active labor significantly increases with an increasing maternal pre-pregnancy BMI in nulliparous women with a spontaneous start of labor. The duration of the pushing phase, defined as the second stage, is inversely associated with maternal BMI, which indicates that the prolonged time in active labor in obese women is restricted to the active phase of first stage labor.

- In nulliparous women with IOL, the duration of active labor increases with maternal BMI, and the difference is most pronounced between underweight and morbidly obese (BMI $\geq 40)$ women. The duration of the latent phase of induced labor successively increases with maternal early pregnancy BMI.

- Maternal plasma leptin levels in obese women are associated with the degree of maternal obesity but not with the degree of GWG based on the IOM's guidelines for obese women. The plasma leptin levels are higher in early and mid pregnancy and postpartum in women with obesity class III than women with obesity class I.

- In a study population that includes a limited number of obese women, maternal leptin levels measured in active labor are not associated with the duration of the active phase of labor when adjusting for possible confounders. If leptin in vivo displays a similar dose-response effect on myometrial contractility as demonstrated in in vitro studies, a larger proportion of the study population may need to be obese to demonstrate this conceivable effect. 


\section{FUTURE PERSPECTIVES}

- To evaluate the labor curves that are used for the clinical assessment of labor progression and consider adapting them for maternal BMI.

- To explore the effect of maternal leptin levels on the duration of labor in obese women.

- To explore the role of oxytocin on labor progression in obese and normal weight women.

- To estimate the total dosage of administered oxytocin over the BMI groups.

- To measure the maternal oxytocin serum levels in relation to the total dosage of oxytocin administered during labor in different maternal BMI classes.

- To investigate the in vitro effects of leptin and oxytocin on human myometrial biopsies obtained after vaginal delivery. 


\section{POPULÄRVETENSKAPLIG SAMMANFATTNING}

Andelen gravida kvinnor med fetma ökar i Sverige liksom i resten av världen. I dag har ca $40 \%$ av alla gravida i Sverige övervikt eller fetma. Fetma innebär att man har ett body mass index $\left(\mathrm{BMI} \mathrm{kg} / \mathrm{m}^{2}\right) \geq 30$ och brukar klassificeras i tre svårighetsgrader efter ökande BMI (klass I = BMI 30-35, klass II = BMI 35-40 och klass III = BMI > 40). Att ha fetma och vara gravid innebär högre risker för både mamman och barnet. I de flesta fall ökar riskerna med stigande fetma grad. Riskerna för mamman inkluderar sjukdomar under graviditet, t ex havandeskapsförgiftning och graviditetsdiabetes. Flera av de förlossningsrelaterade riskerna verkar orsakade av en försämrad förmåga i livmodermuskulaturen att dra ihop sig. Kvinnor med fetma har till exempel en ökad risk att bli överburna d.v.s. att värkarbetet inte startar av sig själv och behöver få medicinsk hjälp med att sätta igång förlossningen. Detta kallas induktion av förlossning och har blivit en mycket vanlig åtgärd i dagens förlossningsvård. Kvinnor med högt BMI har en ökad risk att bli igångsatta men också en ökad risk att igångsättningen misslyckas och leder till ett akut kejsarsnitt. Tidigare studier har även visat att kvinnor med fetma verkar ha ett försämrat värkarbete och att de kräver värkstimulerande medicin i högre utsträckning än normalviktiga kvinnor. Detta bidrar också till den högre frekvensen av kejsarsnitt i denna grupp. Risken att förlösas med kejsarsnitt ökar med stigande BMI och innebär dels risker relaterade till operationen men framförallt för kommande graviditeter och förlossningar. Dagens riktlinjer för vad som är normal tid i förlossningsarbete är samma oavsett om man är normalviktig eller har fetma. Det är viktigt att veta om kvinnor med fetma har en ökad förlossningstid för att omhändertagandet på förlossningsavdelningarna ska bli bra och för att de inte ska utsättas för kejsarsnitt i onödan.

Mekanismen bakom teorin att livmodermuskulaturen fungerar sämre hos kvinnor med fetma är inte klarlagd. Studier på laboratoriet har visat att muskelfibrer från livmodern hos kvinnor med fetma drar ihop sig sämre. I laboratoriemiljö har man även studerat ett hormon, leptin, och visat att det minskar styrka och frekvens av sammandragningarna i muskelfibrer från livmodern. Detta hormon bildas av fettvävnaden och finns i ökad mängd i blodet hos personer med fetma. Under graviditet bildar även moderkakan detta hormon. Gravida kvinnor med fetma har dock högre halter än normalviktiga gravida kvinnor. Höga halter av leptin är förknippat med fetma 
relaterade sjukdomar under graviditet som havandeskapsförgiftning och graviditetsdiabetes.

Det övergripande syftet med denna avhandling var att utvärdera förlossningstiden i relation till mammans BMI och undersöka den kliniska betydelsen av mammans leptinhalt under förlossningen.

I avhandlingens första delarbete undersökte vi om förlossningstiden skiljer sig mellan normalviktiga förstföderskor och de med högt BMI som har spontan start av förlossningen. Vi använde data från graviditetsdatabasen Perinatal Revision Syd och fann bland 63,829 förstföderskor en signifikant längre förlossningstid hos kvinnor med högt BMI jämfört med normalviktiga kvinnor (BMI 18.5-25). Vi undersökte då också hur länge man krystade och fann att krystningstiden är kortare hos kvinnor med fetma än hos normalviktiga.

I den andra delstudien undersökte vi om förlossningstiden hos förstföderskor med igångsatt förlossning skiljer sig mellan normalviktiga kvinnor och kvinnor med fetma. Vi använde i detta arbete data från det nationella svenska graviditesregistret och fann bland 15,259 igångsatta förstföderskor att förlossningstiden är signifikant längre hos kvinnor med sjuklig fetma (klass III, BMI $\geq 40$ ) jämfört med normalviktiga. Vi studerade två olika faser av förlossningen, dels den första förberedande latensfasen och dels den aktiva fasen. Det visade sig att mammans BMI verkar ha större effekt på tiden i latensfas som ökade med stigande BMI klass. Skillnaderna mellan BMI grupperna var inte lika tydliga i den aktiva fasen.

I avhandlingens tredje delarbete studerade vi 343 kvinnor med fetma. Vi ville undersöka om det var någon skillnad i kvinnans leptinhalt i blodet under graviditet och efter förlossningen mellan de tre fetmaklasserna. I denna studie använde vi oss av sparade blodprover från en tidigare studie på gravida kvinnor med fetma. Mammans leptinhalt var signifikant högre i fetmaklass III jämfört med fetmaklass I vid alla mättillfällena. Vi fann dock inget samband mellan leptinhalt och viktuppgång under graviditeten hos dessa kvinnor.

I den fjärde delstudien mätte vi mammans leptinhalt i blodet vid starten av förlossningsarbetet på 914 kvinnor. Därefter undersökte vi om det fanns ett samband mellan mammans leptinhalt och tiden i förlossningsarbete. De första analyserna visade att förlossningstiden ökade med mammans leptinhalt, men sambandet var inte längre signifikant när vi justerade för ett antal störfaktorer. Möjligen krävs det en större andel kvinnor med högt BMI (som har höga leptinhalter) än vad vi hade i vår studie för att visa om högre halter av leptin hämmar livmodermuskulaturens sammandragningar ännu mer. 


\section{ACKNOWLEDGEMENTS}

There are many people who have encouraged and supported me through this $\mathrm{PhD}$ project and I am grateful to you all. Without you, I could not have done this. In particular, I would like to thank:

Associate professor Marie Blomberg, my excellent main supervisor and friend. I am deeply grateful for your indispensable support and splendid guidance at every stage of this journey. Thank you for sharing your great knowledge and for always being available. I admire your inspiring enthusiasm, wisdom and positive mind. You are a true role model!

Professor Karin Källén, my co-supervisor, for your immense statistical knowledge and intelligent solutions. For your hospitality during my visits in Lund and for having the patience to answer and explain all statistical questions I have asked over and over again. This thesis would never exist without you.

Professor Jan Brynhildsen, my co-supervisor, for good advice and support, for your positive attitude and valuable and constructive criticism of the papers included in this thesis.

Associate professor Annika Thorsell for introducing me to the laboratory world and sharing your skills and knowledge.

Lars Valter for clever statistical solutions in paper III.

Marie Nelson for excellent and invaluable help with data extraction from obstetrix.

Karin Söderman for help and quick answers on biobank/GRABB issues.

All women participating in GRABB and the staff at the antenatal care clinic in Linköping and Motala for recruiting patients to GRABB.

The staff at the delivery ward in Linköping for helping out with patients included in GRABB and for a nice and cheerful working environment.

Senior Professor Mats Hammar for introducing me into the field of re- 
search in the first place as a medical student.

Professor Preben Kjölhede, Dr Elizabeth Nedstrand, Associate professor Anna-Clara Spetz Holm, Dr Caroline Lilliecreutz, Dr Ninnie Borendal Wodlin and Dr Kristina Kernell for skillful reflections and valuable comments on the thesis and manuscripts.

Dr Ninnie Borendal Wodlin, head of the Department of Obstetrics and Gynecology in Linköping, Dr Annika Jeppsson, Dr Elizabeth Nedstrand, Dr Charlotte Ginstman and Dr Kristina Kernell, for giving me research time and opportunity to complete this thesis and creating a schedule allowing this.

My fellow PhD students and research colleagues in "FOPP" for support, fruitful discussions, laughs and fun times together.

All my friends and fantastic colleagues at the department of Obstetrics and Gynecology in Linköping, for your support and for making it interesting and fun to go to work.

All my dear and fantastic friends, for support and pleasant times off work. You are all very important to me and I am grateful to have you in my life.

My fantastic parents in law Helena and Lars, for your love and support, help with our children and joyful times together.

My wonderful father Björn, and my amazing mother Elisabeth, when she lived, for your love and generosity and for always supporting and believing in me throughout life. I am so grateful for everything that you have done for me and my family.

My dearest sister Hanna and your lovely family. Thank you for all for fun times together and for always being there. Hanna - I am so lucky to have you as my sister.

Alva, Anton and Gustav, my wonderful children and my greatest gift in life. Thank you for all the happiness, love and pride you bring me. Calle, my beloved husband and life companion. Thank you for always being encouraging and supporting. Without your love, positive mind, technical and daily life support this thesis would not have been possible. I love you all! 


\section{REFERENCES}

1. Obesity: preventing and managing the global epidemic. Report of a WHO consultation. World Health Organization technical report series. 2000;894:i-xii, 1-253. 2. Modder J, Fitzsimons KJ. CMACE/RCOG Joint Guideline. Management of Women with Obesity in Pregnancy https://www.rcog.org.uk/globalassets/documents/guidelines/cmacercogjointguidelinema nagementwomenobesitypregnancya.pdf: The Centre for Maternal and Child Enquiries and the Royal College of Obstetricians and Gynaecologists, 2010.

$3 . \quad$ Collaboration NCDRF. Trends in adult body-mass index in 200 countries from 1975 to 2014: a pooled analysis of 1698 population-based measurement studies with 19.2 million participants. Lancet. 2016;387:1377-96.

4. Ogden CL, Carroll MD, Kit BK, Flegal KM. Prevalence of childhood and adult obesity in the United States, 2011-2012. JAMA. 2014;311:806-14.

$5 . \quad$. https://www.worldobesity.org/data/map/overview-women: World Obesity Federation, 2018.

6. $\quad$ Statistics on Pregnancies, Deliveries and Newborn Infants 2016. In:

Sweden Oso, (ed). http://www.socialstyrelsen.se/publikationer2018/2018-1-6

: The National Bord of Health and Welfare, 2018.

7. $\quad$ Stang J, Huffman LG. Position of the Academy of Nutrition and Dietetics: Obesity, Reproduction, and Pregnancy Outcomes. J Acad Nutr Diet. 2016;116:677-91.

8. $\quad$ Cedergren MI. Maternal morbid obesity and the risk of adverse pregnancy outcome. Obstet Gynecol. 2004;103:219-24.

9. Norman JE, Reynolds RM. The consequences of obesity and excess weight gain in pregnancy. The Proceedings of the Nutrition Society. 2011;70:450-6.

10. Torloni MR, Betran AP, Horta BL, Nakamura MU, Atallah AN, Moron AF, et al. Prepregnancy BMI and the risk of gestational diabetes: a systematic review of the literature with meta-analysis. Obesity reviews : an official journal of the International Association for the Study of Obesity. 2009;10:194-203.

11. Poobalan AS, Aucott LS, Gurung T, Smith WC, Bhattacharya S. Obesity as an independent risk factor for elective and emergency caesarean delivery in nulliparous women--systematic review and meta-analysis of cohort studies. Obesity reviews : an official journal of the International Association for the Study of Obesity. 2009;10:28-35.

12. Weiss JL, Malone FD, Emig D, Ball RH, Nyberg DA, Comstock CH, et al. Obesity, obstetric complications and cesarean delivery rate--a population-based screening study. American journal of obstetrics and gynecology. 2004;190:1091-7. 13. Barau G, Robillard PY, Hulsey TC, Dedecker F, Laffite A, Gerardin P, et al. Linear association between maternal pre-pregnancy body mass index and risk of caesarean section in term deliveries. BJOG : an international journal of obstetrics and gynaecology. 2006;113:1173-7.

14. Carlson NS, Hernandez TL, Hurt KJ. Parturition dysfunction in obesity: time to target the pathobiology. Reprod Biol Endocrinol. 2015;13:135.

15. Cedergren M. Effects of gestational weight gain and body mass index on obstetric outcome in Sweden. International journal of gynaecology and obstetrics: the 
official organ of the International Federation of Gynaecology and Obstetrics. 2006;93:269-74.

16. Nohr EA, Vaeth M, Baker JL, Sorensen T, Olsen J, Rasmussen KM. Combined associations of prepregnancy body mass index and gestational weight gain with the outcome of pregnancy. Am J Clin Nutr. 2008;87:1750-9.

17. Nohr EA, Vaeth M, Baker JL, Sorensen TI, Olsen J, Rasmussen KM. Pregnancy outcomes related to gestational weight gain in women defined by their body mass index, parity, height, and smoking status. The American journal of clinical nutrition. 2009;90:1288-94.

18. Kapadia MZ, Park CK, Beyene J, Giglia L, Maxwell C, McDonald SD. Can we safely recommend gestational weight gain below the 2009 guidelines in obese women? A systematic review and meta-analysis. Obesity reviews : an official journal of the International Association for the Study of Obesity. 2015;16:189-206.

19. Devlieger R, Benhalima K, Damm P, Van Assche A, Mathieu C, Mahmood T, et al. Maternal obesity in Europe: where do we stand and how to move forward?: A scientific paper commissioned by the European Board and College of Obstetrics and Gynaecology (EBCOG). Eur J Obstet Gynecol Reprod Biol. 2016;201:203-8.

20. Bogaerts A, Van den Bergh BR, Ameye L, Witters I, Martens E, Timmerman D, et al. Interpregnancy weight change and risk for adverse perinatal outcome. Obstetrics and gynecology. 2013;122:999-1009.

21. Goldstein RF, Abell SK, Ranasinha S, Misso M, Boyle JA, Black MH, et al. Association of Gestational Weight Gain With Maternal and Infant Outcomes: A Systematic Review and Meta-analysis. JAMA. 2017;317:2207-25.

22. Rasmussen KM, Catalano PM, Yaktine AL. New guidelines for weight gain during pregnancy: what obstetrician/gynecologists should know. Current opinion in obstetrics \& gynecology. 2009;21:521-6.

23. Blomberg M. Maternal and neonatal outcomes among obese women with weight gain below the new Institute of Medicine recommendations. Obstetrics and gynecology. 2011;117:1065-70.

24. Bodnar LM, Siega-Riz AM, Simhan HN, Himes KP, Abrams B. Severe obesity, gestational weight gain, and adverse birth outcomes. The American journal of clinical nutrition. 2010;91:1642-8.

25. Bogaerts A, Witters I, Van den Bergh BR, Jans G, Devlieger R. Obesity in pregnancy: altered onset and progression of labour. Midwifery. 2013;29:1303-13.

26. Norwitz ER, Robinson JN, Challis JR. The control of labor. N Engl J Med. 1999;341:660-6.

27. Irani RA, Foster S. Overview of the mechanisms of induction of labor. Semin Perinatol. 2015;39:426-9.

28. Wray S. Insights into the uterus. Exp Physiol. 2007;92:621-31.

29. Friedman EA. Primigravid labor; a graphicostatistical analysis. Obstetrics and gynecology. 1955;6:567-89.

30. Zhang J, Landy HJ, Branch DW, Burkman R, Haberman S, Gregory KD, et al. Contemporary patterns of spontaneous labor with normal neonatal outcomes. Obstet Gynecol. 2010;116:1281-7.

31. Zhang J, Troendle J, Mikolajczyk R, Sundaram R, Beaver J, Fraser W. The natural history of the normal first stage of labor. Obstet Gynecol. 2010;115:705-10. 32. Z Zhang J, Troendle JF, Yancey MK. Reassessing the labor curve in nulliparous women. Am J Obstet Gynecol. 2002;187:824-8. 

Progression of the first stage of spontaneous labour: A prospective cohort study in two sub-Saharan African countries. PLoS Med. 2018;15:e1002492.

34. Intrapartum care for healthy women and babies. 2014

https://www.nice.org.uk/guidance/cg190/chapter/Recommendations - latent-first-stageof-labour: NICE Guidelines., December, 2014.

$35 . \quad H a n l e y$ GE, Munro S, Greyson D, Gross MM, Hundley V, Spiby H, et al. Diagnosing onset of labor: a systematic review of definitions in the research literature. BMC Pregnancy Childbirth. 2016;16:71.

36. Chelmow D, Kilpatrick SJ, Laros RK, Jr. Maternal and neonatal outcomes after prolonged latent phase. Obstet Gynecol. 1993;81:486-91.

37. Programme WHODoFHMHaSM. Preventing prolonged labor: A practical guide. The partograph Part I: Principles and Strategy. World Health Organization. . http://apps.who.int/iris/bitstream/10665/58903/1/WHO_FHE_MSM_93.8.pdf.1994.

38. Oladapo OT, Tuncalp O, Bonet M, Lawrie TA, Portela A, Downe S, et al. WHO model of intrapartum care for a positive childbirth experience: Transforming care of women and babies for improved health and well-being. BJOG : an international journal of obstetrics and gynaecology. 2018;

39. WHO recommendations: intrapartum care for a positive childbirth experience. . http://www.who.int/reproductivehealth/publications/intrapartum-careguidelines/en/: Geneva: World Health Organization.Licence: CC BY-NC-SA 3.0 IGO., 2018.

40. Normal labour practice. In Swedish: Handläggning av normal förlossning State of the art. https://www.sfog.se/media/66770/state_of_the_art_pn.pdf: Swedish National Board of Health and Welfare. , 2001.

41. Definition of active labour. In Swedish: Definition av etablerat förlossningsarbete. http://www.barnmorskeforbundet.se/aktuellt/forbundet/definitionetablerat-forlossningsarbete/: Swedish Association of Midwifes and Swedish Society of Obstetrics and Gynecology., 2015

42. American College of O, Gynecologists, Society for Maternal-Fetal M. Obstetric care consensus no. 1: safe prevention of the primary cesarean delivery. Obstet Gynecol. 2014;123:693-711.

43. Cheng YW, Shaffer BL, Bryant AS, Caughey AB. Length of the first stage of labor and associated perinatal outcomes in nulliparous women. Obstet Gynecol. 2010;116:1127-35.

44. Harper LM, Caughey AB, Roehl KA, Odibo AO, Cahill AG. Defining an abnormal first stage of labor based on maternal and neonatal outcomes. Am J Obstet Gynecol. 2014;210:536 e1-7.

45. Kominiarek MA, Zhang J, Vanveldhuisen P, Troendle J, Beaver J, Hibbard JU. Contemporary labor patterns: the impact of maternal body mass index. Am J Obstet Gynecol. 2011;205:244 e1-8.

46. Hermesch AC, Allshouse AA, Heyborne KD. Body Mass Index and the Spontaneous Onset of Parturition. Obstet Gynecol. 2016;128:1033-8.

47. Denison FC, Price J, Graham C, Wild S, Liston WA. Maternal obesity, length of gestation, risk of postdates pregnancy and spontaneous onset of labour at term. BJOG : an international journal of obstetrics and gynaecology. 2008;115:720-5.

48. Roos N, Sahlin L, Ekman-Ordeberg G, Kieler H, Stephansson O. Maternal risk factors for postterm pregnancy and cesarean delivery following labor induction. Acta Obstet Gynecol Scand. 2010;89:1003-10. 
49.

Vahratian A, Zhang J, Troendle JF, Savitz DA, Siega-Riz AM. Maternal prepregnancy overweight and obesity and the pattern of labor progression in term nulliparous women. Obstet Gynecol. 2004;104:943-51.

50. Hilliard AM, Chauhan SP, Zhao Y, Rankins NC. Effect of obesity on length of labor in nulliparous women. Am J Perinatol. 2012;29:127-32.

51. Norman SM, Tuuli MG, Odibo AO, Caughey AB, Roehl KA, Cahill AG. The effects of obesity on the first stage of labor. Obstet Gynecol. 2012;120:130-5.

52. Robinson BK, Mapp DC, Bloom SL, Rouse DJ, Spong CY, Varner MW, et al. Increasing maternal body mass index and characteristics of the second stage of labor. Obstet Gynecol. 2011;118:1309-13.

53. Buhimschi CS, Buhimschi IA, Malinow AM, Weiner CP. Intrauterine pressure during the second stage of labor in obese women. Obstet Gynecol. 2004;103:225-30.

54. Fyfe EM, Anderson NH, North RA, Chan EH, Taylor RS, Dekker GA, et al. Risk of first-stage and second-stage cesarean delivery by maternal body mass index among nulliparous women in labor at term. Obstet Gynecol. 2011;117:1315-22.

55. Zhang J, Bricker L, Wray S, Quenby S. Poor uterine contractility in obese women. BJOG : an international journal of obstetrics and gynaecology. 2007;114:343-8. 56. Cedergren MI. Non-elective caesarean delivery due to ineffective uterine contractility or due to obstructed labour in relation to maternal body mass index. Eur $\mathrm{J}$ Obstet Gynecol Reprod Biol. 2009;145:163-6.

57. Verdiales M, Pacheco C, Cohen WR. The effect of maternal obesity on the course of labor. J Perinat Med. 2009;37:651-5.

58. Roloff K, Peng S, Sanchez-Ramos L, Valenzuela GJ. Cumulative oxytocin dose during induction of labor according to maternal body mass index. Int J Gynaecol Obstet. 2015;131:54-8.

59. Pevzner L, Powers BL, Rayburn WF, Rumney P, Wing DA. Effects of maternal obesity on duration and outcomes of prostaglandin cervical ripening and labor induction. Obstet Gynecol. 2009;114:1315-21.

60. Higgins CA, Martin W, Anderson L, Blanks AM, Norman JE, McConnachie A, et al. Maternal obesity and its relationship with spontaneous and oxytocin-induced contractility of human myometrium in vitro. Reprod Sci. 2010;17:177-85.

61. Muir R, Ballan J, Clifford B, McMullen S, Khan R, Shmygol A, et al. Modelling maternal obesity: the effects of a chronic high-fat, high-cholesterol diet on uterine expression of contractile-associated proteins and ex vivo contractile activity during labour in the rat. Clin Sci (Lond). 2016;130:183-92.

62. Davey MA, King J. Caesarean section following induction of labour in uncomplicated first births- a population-based cross-sectional analysis of 42,950 births. BMC Pregnancy Childbirth. 2016;16:92.

63. Thorsell M, Lyrenas S, Andolf E, Kaijser M. Induction of labor and the risk for emergency cesarean section in nulliparous and multiparous women. Acta Obstet Gynecol Scand. 2011;90:1094-9.

64. Arrowsmith S, Wray S, Quenby S. Maternal obesity and labour complications following induction of labour in prolonged pregnancy. BJOG : an international journal of obstetrics and gynaecology. 2011;118:578-88.

65. O'Dwyer V, O'Kelly S, Monaghan B, Rowan A, Farah N, Turner MJ. Maternal obesity and induction of labor. Acta Obstet Gynecol Scand. 2013;92:1414-8. 66. Wolfe KB, Rossi RA, Warshak CR. The effect of maternal obesity on the rate of failed induction of labor. Am J Obstet Gynecol. 2011;205:128 e1-7. 
67. Nuthalapaty FS, Rouse DJ, Owen J. The association of maternal weight with cesarean risk, labor duration, and cervical dilation rate during labor induction. Obstet Gynecol. 2004;103:452-6.

68. Lassiter JR, Holliday N, Lewis DF, Mulekar M, Abshire J, Brocato B. Induction of labor with an unfavorable cervix: how does BMI affect success? (double dagger). J Matern Fetal Neonatal Med. 2016;29:3000-2.

69. Frederiks F, Lee S, Dekker G. Risk factors for failed induction in nulliparous women. J Matern Fetal Neonatal Med. 2012;25:2479-87.

70. Walsh J, Foley M, O'Herlihy C. Dystocia correlates with body mass index in both spontaneous and induced nulliparous labors. J Matern Fetal Neonatal Med. 2011;24:817-21.

71. Hirshberg A, Levine LD, Srinivas S. Labor length among overweight and obese women undergoing induction of labor. J Matern Fetal Neonatal Med. 2014;27:1771-5.

72. Ostborg TB, Romundstad PR, Eggebo TM. Duration of the active phase of labor in spontaneous and induced labors. Acta Obstet Gynecol Scand. 2017;96:120-7. 73. Harper LM, Caughey AB, Odibo AO, Roehl KA, Zhao Q, Cahill AG. Normal progress of induced labor. Obstet Gynecol. 2012;119:1113-8.

$74 . \quad$ Ouchi N, Parker JL, Lugus JJ, Walsh K. Adipokines in inflammation and metabolic disease. Nat Rev Immunol. 2011;11:85-97.

75. Considine RV, Sinha MK, Heiman ML, Kriauciunas A, Stephens TW, Nyce MR, et al. Serum immunoreactive-leptin concentrations in normal-weight and obese humans. The New England journal of medicine. 1996;334:292-5.

76. Kennedy A, Gettys TW, Watson P, Wallace P, Ganaway E, Pan Q, et al. The metabolic significance of leptin in humans: gender-based differences in relationship to adiposity, insulin sensitivity, and energy expenditure. The Journal of clinical endocrinology and metabolism. 1997;82:1293-300.

77. Perez-Perez A, Toro A, Vilarino-Garcia T, Maymo J, Guadix P, Duenas JL, et al. Leptin action in normal and pathological pregnancies. J Cell Mol Med. 2018;22:716-27.

$78 . \quad$ Sam Dagogo-Jack eDGB. Leptin : regulation and clinical applications. Cham, Switzerland:Springer, 2015, 2015.

79. Liu J, Askari H, Dagogo-Jack S. Reproducibility of fasting plasma leptin concentration in lean and obese humans. Endocr Res. 1999;25:1-10.

80. Tessier DR, Ferraro ZM, Gruslin A. Role of leptin in pregnancy: consequences of maternal obesity. Placenta. 2013;34:205-11.

81. Franco-Sena AB, de Oliveira LC, de Jesus Pereira Pinto T, Farias DR, Vaz Jdos S, Kac G. Factors associated with prospective leptin concentrations throughout pregnancy in pregestational normal weight, overweight and obese women. Clin Endocrinol (Oxf). 2015;82:127-35.

82. Yang MJ. Interrelationships of maternal serum leptin, body mass index and gestational age. J Chin Med Assoc. 2005;68:452-7.

83. Highman TJ, Friedman JE, Huston LP, Wong WW, Catalano PM. Longitudinal changes in maternal serum leptin concentrations, body composition, and resting metabolic rate in pregnancy. American journal of obstetrics and gynecology. 1998;178:1010-5.

84. $\quad$ van der Wijden CL, Delemarre-van der Waal HA, van Mechelen W, van Poppel MN. The concurrent validity between leptin, BMI and skin folds during pregnancy and the year after. Nutrition \& diabetes. 2013;3:e86. 
85.

Misra VK, Trudeau S. The influence of overweight and obesity on longitudinal trends in maternal serum leptin levels during pregnancy. Obesity. 2011;19:416-21.

86. $\quad$ Castellano Filho DS, do Amaral Correa JO, Dos Santos Ramos P, de Oliveira Montessi M, Aarestrup BJ, Aarestrup FM. Body weight gain and serum leptin levels of non-overweight and overweight/obese pregnant women. Medical science monitor : international medical journal of experimental and clinical research.

2013;19:1043-9.

87. Catalano PM. Trying to understand gestational diabetes. Diabet Med. 2014;31:273-81.

88. Spradley FT, Palei AC, Granger JP. Increased risk for the development of preeclampsia in obese pregnancies: weighing in on the mechanisms. Am J Physiol Regul Integr Comp Physiol. 2015;309:R1326-43.

89. Dos Santos E, Duval F, Vialard F, Dieudonne MN. The roles of leptin and adiponectin at the fetal-maternal interface in humans. Horm Mol Biol Clin Investig. 2015;24:47-63.

90. Wendremaire M, Bardou M, Peyronel C, Hadi T, Sagot P, Morrison JJ, et al. Effects of leptin on lipopolysaccharide-induced myometrial apoptosis in an in vitro human model of chorioamnionitis. American journal of obstetrics and gynecology. 2011;205:363 e1-9.

91. Wendremaire M, Mourtialon P, Goirand F, Lirussi F, Barrichon M, Hadi $\mathrm{T}$, et al. Effects of leptin on lipopolysaccharide-induced remodeling in an in vitro model of human myometrial inflammation. Biol Reprod. 2013;88:45.

92. Moynihan AT, Hehir MP, Glavey SV, Smith TJ, Morrison JJ. Inhibitory effect of leptin on human uterine contractility in vitro. American journal of obstetrics and gynecology. 2006;195:504-9.

93. Barrichon M, Hadi T, Wendremaire M, Ptasinski C, Seigneuric R, Marcion G, et al. Dose-dependent biphasic leptin-induced proliferation is caused by non-specific IL-6/NF-kappaB pathway activation in human myometrial cells. Br J Pharmacol. 2015;172:2974-90.

94. Mumtaz S, AlSaif S, Wray S, Noble K. Inhibitory effect of visfatin and leptin on human and rat myometrial contractility. Life sciences. 2015;125:57-62.

95. Wuntakal R, Kaler M, Hollingworth T. Women with high BMI: should they be managed differently due to antagonising action of leptin in labour? Med Hypotheses. 2013;80:767-8.

96. AlSaif S, Mumtaz S, Wray S. A short review of adipokines, smooth muscle and uterine contractility. Life sciences. 2015;125:2-8.

97. Molin J. A regional perinatal database in southern Sweden--a basis for quality assurance in obstetrics and neonatology. Acta Obstet Gynecol Scand Suppl. 1997;164:37-9.

98. Stephansson O, Petersson K, Bjork C, Conner P, Wikstrom AK. The Swedish Pregnancy Register - for quality of care improvement and research. Acta Obstet Gynecol Scand. 2018;97:466-76.

99. Claesson IM, Sydsjo G, Brynhildsen J, Cedergren M, Jeppsson A, Nystrom F, et al. Weight gain restriction for obese pregnant women: a case-control intervention study. BJOG : an international journal of obstetrics and gynaecology. 2008;115:44-50.

100. Messerlian C, Basso O. Cohort studies in the context of obstetric and gynecologic research: a methodologic overview. Acta Obstet Gynecol Scand. 2018;97:371-9. 
101. Natamba BK, Sanchez SE, Gelaye B, Williams MA. Concordance between self-reported pre-pregnancy body mass index (BMI) and BMI measured at the first prenatal study contact. BMC Pregnancy Childbirth. 2016;16:187.

102. Seijo M, Minckas N, Cormick G, Comande D, Ciapponi A, BelizAn JM. Comparison of self-reported and directly measured weight and height among women of reproductive age: a systematic review and meta-analysis. Acta Obstet Gynecol Scand. 2018;97:429-39.

103. Ananth CV, Schisterman EF. Confounding, causality, and confusion: the role of intermediate variables in interpreting observational studies in obstetrics. Am J Obstet Gynecol. 2017;217:167-75.

104. Beyer DA, Amari F, Ludders DW, Diedrich K, Weichert J. Obesity decreases the chance to deliver spontaneously. Archives of gynecology and obstetrics. 2011;283:981-8.

105. Zelig CM, Nichols SF, Dolinsky BM, Hecht MW, Napolitano PG. Interaction between maternal obesity and Bishop score in predicting successful induction of labor in term, nulliparous patients. Am J Perinatol. 2013;30:75-80. 


\section{Papers}

The papers associated with this thesis have been removed for copyright reasons. For more details about these see:

http://urn.kb.se/resolve?urn=urn:nbn:se:liu:diva-147650 